\title{
Bioaccessible arsenic in soil of thermal areas of Viterbo, Central Italy: implications for human health risk
}

\author{
V. Rimondi (iD $\cdot$ P. Costagliola $\cdot$ P. Lattanzi $\cdot$ T. Catelani $\cdot$ S. Fornasaro $\cdot$ \\ D. Medas • G. Morelli • M. Paolieri
}

Received: 25 May 2020/Accepted: 26 March 2021/Published online: 21 April 2021

(C) The Author(s) 2021

\begin{abstract}
Thermal waters near the city of Viterbo (Central Italy) are known to show high As contents (up to $600 \mu \mathrm{g} / \mathrm{l})$. Travertine is precipitated by these waters, forming extended plateau. In this study, we determine the As content, speciation and bioaccessibility in soil and travertine samples collected near a recreational area highly frequented by local inhabitants and tourists to investigate the risk of As exposure through accidental ingestion of soil particles. (Pseudo)total contents in the studied soils range from 17 to $528 \mathrm{mg} / \mathrm{kg}$, being higher in soil developed on a
\end{abstract}

Supplementary Information The online version contains supplementary material available at https://doi.org/10.1007/ s10653-021-00914-1.

V. Rimondi $(\bowtie) \cdot$ P. Costagliola .

S. Fornasaro $\cdot$ M. Paolieri

Dipartimento di Scienze della Terra, Università di

Firenze, Via G. La Pira 4, 50121 Florence, Italy

e-mail: valentina.rimondi@unifi.it

V. Rimondi · P. Costagliola · P. Lattanzi - G. Morelli CNR- IGG, Via G. La Pira 4, 50121 Florence, Italy

T. Catelani

Piattaforma di Microscopia, Università di Milano-

Bicocca, Piazza della Scienza 2, 20126 Milan, Italy

D. Medas

Dipartimento di Scienze Chimiche e Geologiche, Università di Cagliari, Cittadella Universitaria di Monserrato - Blocco A, S.S. 554 bivio per Sestu, 09042 Monserrato, CA, Italy travertine substrate $(197 \pm 127 \mathrm{mg} / \mathrm{kg})$ than on volcanic rocks ( $37 \pm 13 \mathrm{mg} / \mathrm{kg})$. In travertines, most As is bound to the carbonatic fraction, whereas in soil the semimetal is mostly associated with the oxide and residual fractions. Accordingly, bioaccessibility (defined here by the simplified bioaccessibility extraction test, SBET; Oomen et al., 2002.) is maximum (up to $139 \mathrm{mg} / \mathrm{kg}$ ) for soil developed on a travertine substrate, indicating a control of calcite dissolution on As bioaccessibility. On the other hand, risk analysis suggests a moderate carcinogenic risk associated with accidental soil ingestion, while dermal contact is negligible. By contrast, ingestion of thermal water implies a higher carcinogenic and systemic health risk.

Keywords Arsenic - Bioaccessibility - Calcite . Geogenic $\cdot$ Soil ingestions $\cdot$ Thermal springs

\section{Introduction}

Arsenic (As) contamination of drinking water, air, food and beverages is a major global health issue, affecting more than 300 million people worldwide (Quansah et al., 2015). The consequences of exposure to As for human health are severe, ranging from dermatologic manifestations to carcinogenic and systemic non-carcinogenic effects.

Geothermal As is common in active and former continental-volcanic settings such as in New Zealand, 
the Andes, Southern Italy, and to a lesser extent in oceanic-volcanic terrains (Ravenscroft et al., 2009). Besides, As spreads in the environment as a consequence of changing redox conditions, which trigger As mobilization from adsorbing mineral phases. This is especially testified in floodplains and/or rice paddy fields, which commonly undergo flooding/non-flooding conditions during their agricultural seasons (e.g., Kim et al., 2021). Arsenic contents of uncontaminated soils worldwide range from 1 to $100 \mathrm{mg} / \mathrm{kg}$, but in general As levels are mostly below $10 \mathrm{mg} / \mathrm{kg}$, and often below $5 \mathrm{mg} / \mathrm{kg}$ (Ravenscroft et al., 2009). As indicated by the EuroGeoSurveys database (Salminen et al., 2005), As is unevenly distributed among topsoils of European countries, displaying significant enrichment in southern Europe (Italy, France and Spain) with respect to Scandinavia $(10.5-2.3 \mathrm{mg} / \mathrm{kg}$, respectively), reflecting the soil finer nature and the long weathering history (Reimann et al., 2009). The As enrichment in soils is indeed considered one of the causes of the higher incidence of dementia in some European countries, among others Italy, France and Spain (Dani, 2010).

Ingestion of contaminated drinking water and food is the primary route to As exposure for humans (Polya \& Lawson, 2016). However, incidental ingestion of As-contaminated soil is a significant exposure pathway through hand-to-mouth transfer during outdoor activities. This is especially true for children (2-6 years old; Calabrese et al., 1989; Kwon et al., 2004), who ingest soil both deliberately and involuntarily by putting dirty hands and objects in their mouths, and are hence exposed to the risk associated with this behavior (Ljung et al., 2007). Once ingested, the risk for human health is associated with As bioavailability, defined as the fraction of an ingested dose that crosses the gastrointestinal epithelium and becomes available for absorption by internal tissues (US EPA, 2007a). Bioavailability can be determined by in vivo studies (Bradham et al., 2018). In the last decades, As bioaccessibility, i.e., the As fraction soluble in the gastrointestinal tract and available for absorption (Rodriguez et al., 1999; Ruby et al., 1999; US EPA, 2007a), is often employed as a surrogate of bioavailability. To estimate bioaccessibility, in vitro simulations of gastrointestinal fluids are carried on. For this purpose, different extractant methods have been established (Bradham et al., 2018 and reference therein). Among them, the simplified bioaccessibility extraction test (SBET) (Oomen et al., 2002; US EPA, 2007b), which simulates the action of gastric juices in a single step, has been extensively used by many researchers (Bagherifam et al., 2014; Mingot et al., 2011; Smith et al., 2008), and validated with in vivo tests (Juhasz et al., 2014).

Linear regression analysis and hierarchical modeling employing soil physicochemical properties, such as the soil elemental composition, $\mathrm{pH}$, mineralogy, particle size, soil aging, have been frequently employed to predict As bioaccessibility (Appleton et al., 2012; Cave et al., 2003; Juhasz et al., 2007; Karna et al., 2017; Martínez-Sánchez et al., 2013; Nelson et al., 2018). On the other hand, selective/ sequential chemical extractions (SEC) and synchrotron radiation investigations (Kim et al., 2014; Mikutta et al., 2014) can be used to unravel As solid phase speciation, identifying the mineral pools which contribute at most of the bioaccessible As from the in vitro tests. Moreover, the knowledge of the solid phases hosting bioaccessible As helps predicting the environmental processes which enhance As bioaccessibility through destabilization of the mineral carrier phases. In soils, Fe oxy(hydr)oxides have the prominent role in controlling As bioaccessibility (Hiller et al., 2018). Specifically, amorphous and poorly crystalline Fe oxy(hydr)oxides increase As bioaccessibility, whereas crystalline phases reduce it (Girouard \& Zagury, 2009; Kim et al., 2014; Mikutta et al., 2014; Palumbo-Roe et al., 2015; Smith et al., 2008; Whitacre et al., 2013).

To date, most studies were conducted on soils with low carbonate contents. Carbonates, and especially calcite, may, however, trap significant amounts of As in natural environments (e.g., Costagliola et al., 2013), possibly controlling As bioaccessibility.

In Italy, hotspots of As occur in Central Italy, especially between Tuscany (Benvenuti et al., 2009; Costagliola et al., 2010; Morelli et al., 2017) and Latium, particularly in the province of Viterbo. Here groundwaters from the volcanic aquifer exceed the thresholds established by the European Drinking Water Directive 98/83/EC. Public awareness of the problem grew during the second half of 2010 and led to a widespread use of bottled water for drinking purposes. There is, however, poor awareness of the risk deriving from exposure to As associated with the thermal springs of Viterbo (Central Italy), which are well known to discharge waters rich in As (Cinti et al., 
2019, and references therein). These waters also deposit travertine (Pentecost, 1995), which has formed an extended plateau. Little information is, however, available on As distribution in the carbonate rock itself and in the surrounding soils. In this paper, As distribution is investigated in travertine deposits and soils surrounding these thermal springs; the main goals are: i) to define As distribution in soils in relation to the different geological substrata; ii) to quantify As bioaccessibility and how it is correlated with As fractionation, determined by SBET and sequential extraction procedures, respectively; iii) to estimate the risk associated with the accidental soil ingestion among adults and children in the area.

\section{Study area}

The study area is located few $\mathrm{km}$ west of the city of Viterbo (northern Latium), in the surroundings of the city thermal area (Fig. 1). Geologically, it belongs to the Vicano-Cimino volcanic complex extending between the Tyrrhenian coast and the Apennines chain. Plio-Quaternary extensional tectonics related to the post-collisional phases of Apennines orogeny were responsible for crustal thinning $(<25 \mathrm{~km}$; Scrocca et al., 2003), heat flow anomalies $\left(100-200 \mathrm{~mW} / \mathrm{m}^{2}\right.$; Della Vedova et al., 2001), and the development of subduction-related magmatism (Peccerillo, 2017, and references therein). Specifically, the Vico complex (0.4-0.1 Ma), consisting of volcanic rocks belonging to the Roman Magmatic Province, diffusely crops out in the study area. It consists of silica-oversaturated to silica-undersaturated potassic and ultrapotassic magmas, which partially superimpose on the Mt. Cimini rocks ( 1.3-0.9 Ma) belonging to the Tuscan Magmatic Province. The pre-volcanic substratum is composed by Neogene marine and continental deposits, which filled NW-SE-oriented grabens (Barberi et al., 1994), Upper Cretaceous-Oligocene Flysch (Ligurian Units), Triassic-Paleogene carbonate rocks and evaporites (Tuscan-Marche Units), and Cenozoic turbidite

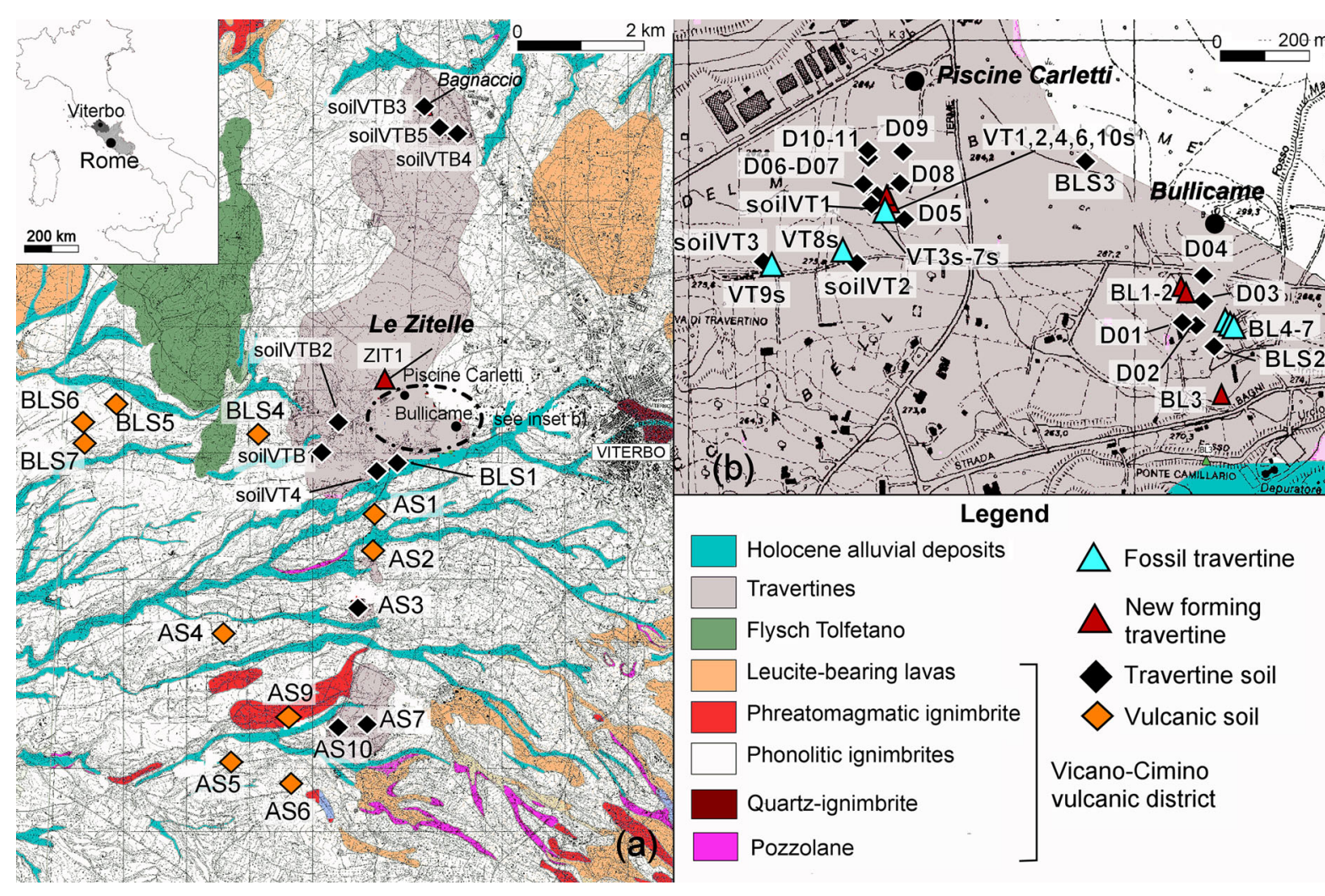

Fig. 1 a Geological map of the Viterbo area and location of samples; the dash-point circled area is enlarged in $\mathbf{b}$; $\mathbf{b}$ detailed map of thermal hot-spring sites of Piscine Carletti and Bullicame 
deposits (Flysch units). The volcanic rocks are covered by Pleistocene-Holocene continental deposits and Holocene travertines, which extend horizontally and sub-horizontally forming vast plateau (Manfra et al., 1976). According to Minissale et al. (2002), the formation of travertines is associated with decarbonation processes affecting Mesozoic units at depth.

In the proximity of the study area, two aquifers were recognized: i) a shallow circulation within the volcanic rocks and ii) a deep circulation confined in the Triassic-Paleogene carbonate rocks, which hosts a thermal reservoir, characterized by high As contents (176-371 $\mu \mathrm{g} / \mathrm{l}$; Angelone et al., 2009). These two aquifers are separated by low-permeability horizons (Flysch Units and/or Pliocene-Pleistocene sedimentary rocks), but interact both vertically and laterally (Baiocchi et al., 2012). West of Viterbo, the reduced thickness of the Flysch units and faulting allows the uprising of thermal waters (Angelone et al., 2009). Hot (54-60 ${ }^{\circ} \mathrm{C}$ ) $\mathrm{H}_{2}$ S-rich spring waters emerge along a $\mathrm{N}-\mathrm{S}$ fault at Bagnaccio, Piscine Carletti, Bullicame and Le Zitelle, where travertine is being deposited in stream beds.

The hot springs close to the city of Viterbo are well known since at least III century B.C. by the Etruscans, when thermal waters were already being used for therapeutic properties. Nowadays, natural springs are employed in the therapies of a variety of medical complaints. The recreational area of Viterbo is visited by thousands of people during the whole year, including children (Strangio and Teodori, 2015). In particular, the Bullicame (also referred as Bullicame west; Pentecost, 1995) and Piscine Carletti (also referred as Bullicame 3; Duchi et al., 1985) sites rise up in a large green area freely open to the public. Here, the waters were artificially channeled to provide bathing water for visitors and local inhabitants. It is a common practice for bathers to spread the white carbonate mud on skin lesions, inhale $\mathrm{H}_{2} \mathrm{~S}$, or drink the mineral waters, which are believed to have healthy effects.

\section{Materials and methods}

\section{Sampling}

Samples were collected inside and around the hot springs of Bullicame and Piscine Carletti (Fig. 1a, b) from soils formed on top of the main geological formations cropping out in the area, as verified in the field. In total, 10 soils developed on volcanic rocks and 26 on travertine were sampled (see Table S1 for GPS coordinates). Some of them were collected from agricultural fields, mainly cultivated for wheat. After the removal of vegetation, wherever present, about $1 \mathrm{~kg}$ of topsoil $(0-10 \mathrm{~cm})$ was collected with a Teflon scoop. Soils are classified as Luvic Endoleptic Phaeozems according to the cartography of Latium Region (Napoli et al., 2019), where additional details on soil main characteristics may be found.

Additionally, travertine mud (i.e., currently precipitating from waters, "new forming" thereafter) and rocky ("fossil") travertine were sampled ( $n=17)$ in three locations (Le Zitelle, Bullicame and Piscine Carletti).

Chemical and mineralogical analysis

Travertine and soil samples were dried at room temperature for one month and then disaggregated with a ceramic mortar. Soils were sieved in two granulometric fractions: (1) the $<2 \mathrm{~mm}$ fraction was used for (pseudo) total metal characterization, according to the Italian law requirement (D.L. 152/2006) and for SEC, and (2) the $<250 \mu \mathrm{m}$ fraction was primarily used for the SBET procedure and for (pseudo) total metal concentrations in samples analyzed for SBET. Representative samples (fossil travertine $(n=4)$, new-forming travertine $(n=6)$, travertine soils $(n=7)$, and volcanic soils $(n=5))$ were analyzed for the whole chemistry by wavelength-dispersive X-ray fluorescence (WD XRF) with a PHILIPS PW 1480.

Loss on ignition (LOI) was measured by gravimetric methods; $0.50 \mathrm{~g}$ of oven-dried (at $105^{\circ} \mathrm{C}$ overnight) samples were heated to $950{ }^{\circ} \mathrm{C}$ in quartz-fiber crucibles for $2 \mathrm{~h}$. The LOI values were employed for major elements calculations (Franzini et al., 1975). The analytical quality was controlled by using international standards, and the relative differences between the results and certified values are less than $5 \%$.

X-ray diffraction (XRD) patterns were collected on the $<250 \mu \mathrm{m}$ fraction of selected soil samples and travertines with a Philips PW 1050/37 instrument, operating with a $\mathrm{Cu}$ anode and a graphite 
monochromator, driven by a PANalytical X'Pert PRO data acquisition system.

All analyses were performed at the Dipartimento di Scienze della Terra, Università di Firenze (Italy).

\section{Aqua regia digestion}

Samples dissolution (on the $<2 \mathrm{~mm}$ fraction) was performed by digestion with aqua regia $\left(\mathrm{HCl} / \mathrm{HNO}_{3}\right.$ $3: 1)$ to quantify the pseudo-total As $\left(\mathrm{As}_{\mathrm{T}-2000}\right)$ concentrations in soils and travertines $(n=53)$. As stated before, the $<250 \mu \mathrm{m}$ soil fraction analyzed for SBET was also digested by aqua regia to determine pseudototal As $\left(\mathrm{As}_{\mathrm{T}-250}\right)$. Digestions were accomplished both by the US EPA 3051 method by microwave digestion (Milestone CEM MARS 6) in pre-cleaned Teflon vessels at $175{ }^{\circ} \mathrm{C}$ for $20 \mathrm{~min}$ and in a sand bath at $50{ }^{\circ} \mathrm{C}$ for $3 \mathrm{~h}$. The last procedure was employed to avoid contamination of Teflon bombs for samples with high As content. The obtained solutions were then filtered to $0.45 \mu \mathrm{m}$ after adequate cooling, diluted to $100 \mathrm{ml}$ volume with Milli-Q water, stored in polyethylene bottles, and later analyzed by inductively coupled plasma optical emission spectroscopy coupled with hydride generation (HG-ICP-OES; PerkinElmer Optima 8000) within 1 week from digestion. Accuracy was evaluated with international standards (Montana Soil, 2711, RTS4, 2710) and internal laboratory standards (among them, a travertine rock). Recovery was between 90 and $100 \%$. Samples were processed together with blanks prepared with the same acid mixture to evaluate potential contamination from the reagents and sample containers. Instrumental detection limits for ICP-OES were $<0.3 \mu \mathrm{g} / \mathrm{l}$.

Reproducibility was checked by duplicate analyses of six random selected samples, and differences were less than $15 \%$.

\section{Simplified bioaccessibility extraction test: SBET}

Soils ( $n=14$, underlined in Table 1$)$ with different As contents (high, low and medium values of the dataset) developed on travertine substratum were selected for the in vitro SBET procedure to quantify the bioaccessible As fraction (As SBET $_{\text {) }}$ (Oomen et al., 2002; Ruby et al., 1999; US EPA, 2012). Around $1 \pm 0.05 \mathrm{~g}$ of $<250 \mu \mathrm{m}$ soil particle size fraction was mixed with a solution of $50 \mathrm{~mL}$ of glycine $(0.4 \mathrm{M})$ at $\mathrm{pH}=1.50 \pm 0.05$ and adjusted with $\mathrm{HCl}(37 \% \mathrm{v} / \mathrm{v})$.
This mixture was rotated end-over-end at $30 \mathrm{rpm}$ for $1 \mathrm{~h}$ at $37^{\circ} \mathrm{C}$. $\mathrm{pH}$ was controlled every $5 \mathrm{~min}(\mathrm{pH}$ acceptable variation should be \pm 0.5 ) and adjusted whenever necessary. The mixture was centrifuged, the supernatant was separated with nitrate cellulose filters $(0.45 \mu \mathrm{m})$, and it was preserved at $4{ }^{\circ} \mathrm{C}$ until analysis. The concentration of As was determined by atomic absorption spectroscopy (AAS) coupled with hydride generation (PerkinElmer Analyst 100). Quality controls involved preparation and analysis of three sample triplicates on six samples (D01, D03, D06, AS10, SOILVTB4 and SOILVT2), and on blank solutions. The relative standard deviation of the replicate analyses was $<4 \%$. Arsenic contents in blank solutions were below the detection limit $(10 \mu \mathrm{g} / \mathrm{L})$.

Relative bioaccessibility-RBA (\%)—was calculated as (Hu et al., 2011; Juhasz et al., 2007):

$\operatorname{RBA}(\%)=\frac{\mathrm{As}_{\mathrm{SBET}}}{\mathrm{As}_{\mathrm{T}-250}} \times 100$,

where $\mathrm{As}_{\mathrm{SBET}}$ and $\mathrm{As}_{\mathrm{T}-250}$ refer to As extracted from SBET and aqua regia digestions $(250 \mu \mathrm{m})$, respectively.

\section{Sequential extraction scheme: SEC}

The As content of specific geochemical fractions of travertine soils can be extracted selectively by using appropriate reagents, and it was here quantified through two SEC procedures. Details of the reagents employed, the solid-to-liquid ratios and extractions times for each As fraction (As non-specifically bound- $\mathrm{A}_{\mathrm{SO} 4}$; As specifically bound- $\mathrm{A}_{\mathrm{PO} 4}$; As associated with carbonates- $\mathrm{A}_{\mathrm{CARB}}$; As associated with amorphous $\mathrm{Fe}$ oxides- $\mathrm{A}_{\mathrm{OX}}$; $\mathrm{As}$ in the residual fraction- $\mathrm{A}_{\mathrm{AR}}$ ) are reported in Table 2. The first scheme $(A)$, made of six extraction steps $(A 1-A 6)$ and modified after Wenzel et al. (2001), was preliminarily applied to four travertines and four soils to screen the main As-hosting phase. Following the preliminary results, to selectively quantify the amount of As associated with carbonates with respect to other mineral phases as a whole, a simplified four-step scheme $A^{*}$ (Costagliola et al., 2013) was applied to other six soil samples. Here, the aqua regia digestion $\left(A_{\mathrm{AR}}{ }^{*}\right)$ was hence directly applied after the step devoted to carbonates $\left(A_{\mathrm{CARB}} *\right)$. Therefore, the sum of As extracted from $A_{\mathrm{OX}}$ to $A_{\mathrm{AR}}\left(\sum \mathrm{As}_{A_{\mathrm{OX}}-A_{\mathrm{AR}}}\right)$ of scheme A should be comparable to the As extracted 
Table 1 Arsenic contents $(\mathrm{mg} / \mathrm{kg})$ of the investigated soils and travertines

\begin{tabular}{|c|c|c|c|c|}
\hline Sample ID & Sample type & Location & $\mathrm{As}_{\mathrm{T}-2000}$ & $\mathrm{As}_{\mathrm{T}-250}$ \\
\hline soilVT1 & Trav soil & Piscine Carletti & 323 & nd \\
\hline soilVT2 & Trav soil & Agricultural area & 495 & 569 \\
\hline soilVT3 & Trav soil & Agricultural area & 321 & nd \\
\hline soilVT4 & Trav soil & Agricultural area & 81 & nd \\
\hline BLS 1 & Trav soil & Agricultural area & 47 & nd \\
\hline BLS 2 & Trav soil & Agricultural area & 90 & nd \\
\hline BLS 3 & Trav soil & Agricultural area & 42 & nd \\
\hline soilVTB1 & Trav soil & Agricultural area & 195 & nd \\
\hline soilVTB2 & Trav soil & Agricultural area & 58 & nd \\
\hline soilVTB3 & Trav soil & Agricultural area & 132 & nd \\
\hline soilVTB4 & Trav soil & Agricultural area & 130 & 104 \\
\hline soilVTB5 & Trav soil & Agricultural area & 119 & nd \\
\hline AS3 & Trav soil & Agricultural area & $255^{\mathrm{a}}$ & nd \\
\hline AS7 & Trav soil & Agricultural area & 528 & 512 \\
\hline AS10 & Trav soil & Agricultural area & 420 & 518 \\
\hline $\mathrm{D} 01$ & Trav soil & Bullicame & $150^{\mathrm{a}}$ & 135 \\
\hline D02 & Trav soil & Bullicame & 152 & 158 \\
\hline$\overline{\mathrm{D} 03}$ & Trav soil & Bullicame & $166^{\mathrm{a}}$ & 151 \\
\hline D04 & Trav soil & Bullicame & 141 & 124 \\
\hline D05 & Trav soil & Piscine Carletti & 164 & 169 \\
\hline D06 & Trav soil & Piscine Carletti & 246 & 252 \\
\hline$\underline{\mathrm{D} 07}$ & Trav soil & Piscine Carletti & 211 & 224 \\
\hline D08 & Trav soil & Piscine Carletti & 186 & 182 \\
\hline D09 & Trav soil & Piscine Carletti & 173 & 166 \\
\hline$\underline{\mathrm{D} 10}$ & Trav soil & Piscine Carletti & 155 & 147 \\
\hline D11 & Trav soil & Piscine Carletti & 152 & nd \\
\hline BLS4 & Vulc soil & Agricultural area & $56^{\mathrm{a}}$ & nd \\
\hline BLS5 & Vulc soil & Agricultural area & 30 & nd \\
\hline BLS6 & Vulc soil & Agricultural area & 32 & nd \\
\hline BLS7 & Vulc soil & Agricultural area & $17^{\mathrm{a}}$ & nd \\
\hline AS1 & Vulc soil & Agricultural area & 26 & nd \\
\hline AS2 & Vulc soil & Agricultural area & 36 & nd \\
\hline AS4 & Vulc soil & Agricultural area & 24 & nd \\
\hline AS5 & Vulc soil & Agricultural area & 53 & nd \\
\hline AS6 & Vulc soil & Agricultural area & 48 & nd \\
\hline AS9 & Vulc soil & Agricultural area & 43 & nd \\
\hline ZIT1 & New-form trav & Le Zitelle & 73 & nd \\
\hline BL1 & New-form trav & Bullicame & 154 & nd \\
\hline BL2 & New-form trav & Bullicame & 206 & nd \\
\hline BL3 & New-form trav & Bullicame & 201 & nd \\
\hline BL4 & Fossil trav & Bullicame & 160 & nd \\
\hline BL5 & Fossil trav & Bullicame & $186^{\mathrm{a}}$ & nd \\
\hline BL7 & Fossil trav & Bullicame & 123 & nd \\
\hline VT1s & New-form trav & Piscine Carletti & 130 & nd \\
\hline VT2s & New-form trav & Piscine Carletti & 80 & nd \\
\hline
\end{tabular}


Table 1 continued

\begin{tabular}{lllll}
\hline Sample ID & Sample type & Location & As $_{\mathrm{T}-2000}$ & As $_{\mathrm{T}-250}$ \\
\hline VT3s & Fossil trav & Piscine Carletti & 195 & nd \\
VT4s & New-form trav & Piscine Carletti & 164 & nd \\
VT5s & New-form trav & Piscine Carletti & 148 & nd \\
VT6s & New-form trav & Piscine Carletti & 168 & nd \\
VT7s & Fossil trav & Piscine Carletti & 50 & nd \\
VT8s & Fossil trav & Piscine Carletti & 39 & nd \\
VT9s & Fossil trav & Piscine Carletti & 276 & nd \\
VT10s & New-form trav & Piscine Carletti & 125 & \\
\hline
\end{tabular}

${ }^{\mathrm{a}}$ Mean of triplicate analysis; reproducibility $<4 \mathrm{mg} / \mathrm{kg}$ As

Underlined samples are those investigated for SBET

nd stands for not determined

from $\mathrm{As}_{\mathrm{AR}}$ * of scheme $A^{*}$. For the sake of simplicity, in the following we will report $\left(\sum \mathrm{As}_{A_{\mathrm{OX}}-A_{\mathrm{AR}}}\right)$ as $A_{\mathrm{AR}}^{\mathrm{SUM}}$, so that it can be directly compared with $A_{\mathrm{AR}}$ *.

Extractions were conducted by weighing $1 \pm 0.05 \mathrm{~g}$ of sample in $50 \mathrm{ml}$ vials and sequentially adding 20-25 $\mathrm{ml}$ of the respective extraction solution (Table 2). After each step, the suspension was centrifuged at 10,000 $\mathrm{g}$ for $15 \mathrm{~min}$, and the supernatant was separated. Only for step $\mathrm{A}_{\mathrm{CARB}}{ }^{*}$ the residue was filtered through $0.45-\mu \mathrm{m}$ paper filter (Whatman 42 ), and the filter microwave digested. The concentration of As was determined by AAS coupled with hydride generation (PerkinElmer Analyst 100).

The analytical quality of the sequential extraction was controlled calculating the As recovery ( $\mathrm{R} \%$ ) as:

As recovery $(\%)=\sum \mathrm{As}_{\mathrm{SEC}} / \mathrm{As}_{\mathrm{T}} \times 100$

where $\Sigma \mathrm{As}_{\mathrm{SEC}}$ is the sum of As extracted from each single extraction step and $\mathrm{As}_{\mathrm{T}}$ is the As extracted from the bulk sample with aqua regia. Recovery was between 84 and $122 \%$. Reproducibility was evaluated by analyzing three samples (D06, D07 and soilVT2) in duplicate. Differences are $<15 \%$ for all extraction steps.

\section{Exposure and human health risk assessment}

Humans exposure to As in the thermal areas of Viterbo may occur via two principal contact routes with contaminated soils and waters, which are (1) oral ingestion and (2) dermal absorption. Based on the data of the present study, we specifically evaluated the human health risk, following the procedure by USEPA (1989) and transposed by the Italian legislation (D.L. 152/2006 and D.L. 4/2008), associated with accidental ingestion of contaminated soils by residents visiting the thermal pools. Moreover, we evaluated the health risk associated with: (1) the oral exposure derived from the voluntary ingestion of thermal waters for depurative purpose; (2) the dermal exposure associated with water (during bathing activities) and soils (including voluntary applications on skin of thermal muds). The cumulative effect of the multiple exposure pathways was hence calculated (see later). Children (age 1-6) and adults' exposure scenarios were considered.

Average daily dose (ADD) (or lifetime average daily dose, LADD), expressed in $\mathrm{mg} / \mathrm{kg}$ day of As from ingestion of soil $\left(\mathrm{ADD}_{\mathrm{s}, \mathrm{ing}}\right)$ or dermal contact $\left(\mathrm{ADD}_{\mathrm{s}, \mathrm{derm}}\right)$ was calculated with the following formula (US EPA, 1989, 1992, 2004):

$$
\begin{aligned}
\mathrm{ADD}_{\mathrm{s}, \text { ing }} & =\frac{C_{\mathrm{s}} \times \mathrm{IR}_{s} \times \mathrm{EF} \times \mathrm{ED} \times \mathrm{CF}_{s}}{\mathrm{BW} \times \mathrm{AT}_{\mathrm{NC}}} \\
\mathrm{ADD}_{\mathrm{s}, \text { derm }} & =\frac{C_{\mathrm{s}} \times \mathrm{SA} \times \mathrm{AF} \times \mathrm{ABS} \times \mathrm{EF} \times \mathrm{ED} \times \mathrm{EV} \times \mathrm{CF}_{s}}{\mathrm{BW} \times \mathrm{AT}_{\mathrm{NC}}}
\end{aligned}
$$

where $C_{\mathrm{s}}$ is the As content in soils in the $<250 \mu \mathrm{m}$ fraction $\left(\mathrm{As}_{\mathrm{T}-250}\right)$ at each sampling site (at those sites we also have the available glycine extractable (i.e., SBET) contents $(\mathrm{mg} / \mathrm{kg})$ ); $\mathrm{IR}_{\mathrm{s}}$ the soil ingestion rate (mg/day); EF the exposure frequency (days/year); ED 
Table 2 Summary of the sequential chemical extraction procedures (A and A*) employed in this study

\begin{tabular}{|c|c|c|c|c|c|}
\hline \multicolumn{2}{|l|}{ Fractions } & \multirow[t]{2}{*}{ Extractant } & \multirow[t]{2}{*}{ Extractions conditions } & \multirow[t]{2}{*}{ SSR** } & \multirow{2}{*}{$\begin{array}{l}\text { Behavioral } \\
\text { classes }\end{array}$} \\
\hline Scheme A & Scheme A* & & & & \\
\hline $\mathrm{A}_{\mathrm{SO} 4}$ & $\mathrm{~A}_{\mathrm{SO} 4}{ }^{*}$ & $0.05 \mathrm{~mol} / \mathrm{L}\left(\mathrm{NH}_{4}\right)_{2} \mathrm{SO}_{4}$ & $4 \mathrm{~h}$ shaking, $25^{\circ} \mathrm{C}$ & $1: 25$ & $\begin{array}{l}\text { Non-specifically } \\
\text { sorbed }\end{array}$ \\
\hline $\mathrm{A}_{\mathrm{PO} 4}$ & $\mathrm{~A}_{\mathrm{PO} 4} *$ & $0.05 \mathrm{~mol} / \mathrm{L}\left(\mathrm{NH}_{4}\right)_{2} \mathrm{PO}_{4}$ & $16 \mathrm{~h}$ shaking, $25^{\circ} \mathrm{C}$ & $1: 25$ & $\begin{array}{l}\text { Specifically } \\
\text { sorbed }\end{array}$ \\
\hline $\mathrm{A}_{\mathrm{CARB}}$ & $\mathrm{A}_{\mathrm{CARB}} *$ & $\begin{array}{l}40 \mathrm{ml} \text { of } 1 \mathrm{~mol} / \mathrm{l} \text { sodium acetate/ } \\
\text { acetic acid buffer; } \mathrm{pH} 5\end{array}$ & $12 \mathrm{~h}$ shaking, $25^{\circ} \mathrm{C}$ & $1: 25$ & $\begin{array}{l}\text { As bound to } \\
\text { carbonates }\end{array}$ \\
\hline $\mathrm{A}_{\mathrm{OX}}$ & nd & $\begin{array}{l}0.2 \mathrm{~mol} / \mathrm{L} \text { NH4-oxalate buffer; } \\
\text { pH } 3.25\end{array}$ & $4 \mathrm{~h}$ shaking in the dark, $25^{\circ} \mathrm{C}$ & $1: 25$ & $\begin{array}{l}\text { As bound to } \\
\text { amorphous } \mathrm{Fe} \\
\text { oxides }\end{array}$ \\
\hline $\mathrm{A}_{\mathrm{OX}+\mathrm{C}}$ & nd & $\begin{array}{l}0.2 \mathrm{~mol} / \mathrm{L} \text { NH4-oxalate } \\
\text { buffer }+0.1 \mathrm{M} \text { ascorbic acid; } \\
\text { pH } 3.25\end{array}$ & 30 min in a sand basin at $96^{\circ} \mathrm{C}$ & $1: 25$ & $\begin{array}{l}\text { As bound to } \\
\text { crystalline Fe } \\
\text { oxides }\end{array}$ \\
\hline $\mathrm{A}_{\mathrm{AR}}$ & $\mathrm{A}_{\mathrm{AR}} *$ & aqua regia; $\mathrm{HCl} / \mathrm{HNO}_{3} 3: 1$ & $\begin{array}{l}3 \mathrm{~h} \text { in sand bath, } 50^{\circ} \mathrm{C} \text { for scheme } \mathrm{A} \text {; } \\
\text { microwave assisted for scheme } \mathrm{A}^{*}\end{array}$ & $1: 20$ & Residual \\
\hline
\end{tabular}

**Solid-to-liquid ratio

The sum of As extracted from $\mathrm{A}_{\mathrm{OX}}$ to $\mathrm{A}_{\mathrm{AR}}\left(\sum \mathrm{As}_{A_{\mathrm{OX}}-A_{\mathrm{AR}}}\right)$ of the scheme $\mathrm{A}$ is comparable to $\mathrm{A}_{\mathrm{AR}}$ * of the scheme $\mathrm{A}^{*}$ (nd stands for not determined)

the exposure duration (years); $\mathrm{EV}$ the event/day; $\mathrm{CF}_{\mathrm{s}}$ the unit conversion factor $\left(10^{-6} \mathrm{~kg} / \mathrm{mg}\right)$; $\mathrm{BW}$ the body weight $(\mathrm{kg}), \mathrm{AT}_{\mathrm{NC}}$ the averaging time for exposure (ED*365 days for non-carcinogenic substances), SA the skin surface area available for contact ( $\mathrm{cm}^{2} /$ event); AF the soil to skin adherence factor $\left(\mathrm{mg} / \mathrm{cm}^{2}\right)$; ABS the absorption factor for the skin (unitless); BW the body weight $(\mathrm{kg})$. For carcinogenic chemicals, the LADD was standardly calculated by substituting $\mathrm{AT}_{\mathrm{C}}$ for $\mathrm{AT}_{\mathrm{NC}}$, where the averaging time corresponds to lifetime (i.e., AT $=70 * 365)$ (US EPA, 1989, 2004).

Similarly, we calculated ADD (or LADD) for water ingestion $\left(\mathrm{ADD}_{\mathrm{w}, \text { ing }}\right)$ or dermal contact $\left(\mathrm{ADD}_{\mathrm{w}, \mathrm{derm}}\right)$ :

$$
\begin{aligned}
& \mathrm{ADD}_{\mathrm{w}, \text { ing }}=\frac{C_{\mathrm{w}} \times \mathrm{IR}_{\mathrm{w}} \times \mathrm{EF} \times \mathrm{ED}}{\mathrm{BW} \times \mathrm{AT}_{\mathrm{NC}}} \\
& A D D_{w, \text { derm }}=\frac{C_{w} \times S A \times P C \times E T \times E F \times E D \times C F_{w}}{B W \times A T_{N C}},
\end{aligned}
$$

where $C_{\mathrm{w}}$ is chemical concentration in water $(\mathrm{mg} / \mathrm{l})$ from the Bullicame and Piscine Carletti thermal pools (Cinti et al., 2019), $\mathrm{IR}_{\mathrm{w}}$ is the volume (l) of drunk thermal water during or soon after the visit to the pools, $\mathrm{PC}$ is the chemical-specific dermal permeability constant $(\mathrm{cm} / \mathrm{hr})$; ET is the exposure time (hours/day);
$\mathrm{CF}_{\mathrm{w}}$ is the volumetric conversion factor for water (1 $\mathrm{l} /$ $1000 \mathrm{~cm}^{3}$ ), and the other variables as described above for Eqs. (2) and (3). Exposure frequency $(E F=100)$ was determined specifically for this study, assuming that local people visit the thermal recreational areas during the weekend (i.e., twice a week). Similarly, we assumed that the consumption of thermal waters for depurative purposes (i.e., $\mathrm{IR}_{\mathrm{w}}$ ) does not exceed a water bottle $(1 \mathrm{l})$ or a quarter of water bottle $(0.25 \mathrm{l})$ in 2 days for adults and children, respectively. These estimates are obviously tentative: to our knowledge, there is no systematic survey of the actual habits of site visitors. The other specific parameters for ADD or LADD calculations are available in Table 3. For adults, ADD or LADD was age-mediated $\left(\mathrm{ADD}_{\mathrm{adj}}\right)$ considering a child (6 years) plus adults ( 24 years) exposure to As, corresponding to a total ED of 30 years.

After exposure assessment, risk characterization was delineated by integrating data about toxicity (dose/response). Arsenic is considered both a threshold and a non-threshold contaminant. For threshold contaminant, a toxic effect is expected when a certain exposure concentration is surpassed (reference dose), while for non-threshold contaminants toxic effects are shown at any level of exposure. The hazard quotient 
Table 3 Summary of the parameters employed for the ADD and LADD ( $\mathrm{mg} / \mathrm{kg}$ day) calculation for soil ingestion, soil dermal, water ingestion and water dermal exposure scenarios

\begin{tabular}{|c|c|c|c|c|c|c|}
\hline \multirow{2}{*}{$\begin{array}{l}\text { Parameters } \\
\text { Soil ingestion exposure }\end{array}$} & \multirow[t]{2}{*}{ Symbol } & \multirow{2}{*}{\multicolumn{2}{|c|}{ Units }} & \multicolumn{2}{|l|}{ Values } & \multirow[t]{2}{*}{ Source } \\
\hline & & & & Children & Adults & \\
\hline Element concentration in water & \multicolumn{2}{|l|}{$\mathrm{C}_{\mathrm{S}}$} & $\mathrm{mg} / \mathrm{kg}$ & \multicolumn{2}{|l|}{ site-specific } & This study \\
\hline Ingestion rate of soil (US EPA)* & \multicolumn{2}{|l|}{$\mathrm{IR}_{\mathrm{S}}$} & mg/day & 40 & 10 & US EPA (2017) \\
\hline Exposure frequency & \multicolumn{2}{|l|}{$\mathrm{EF}$} & days/year & 100 & & This study \\
\hline Exposure duration & \multicolumn{2}{|l|}{$\mathrm{ED}$} & years & 6 & 30 & US EPA (2004) \\
\hline Body weight & \multicolumn{2}{|l|}{ BW } & $\mathrm{kg}$ & 15 & 70 & US EPA (2004) \\
\hline Averaging time (non-cancerogenic) & \multicolumn{2}{|l|}{$\mathrm{AT}_{\mathrm{NC}}$} & days & 2190 & 10,950 & US EPA (1989) \\
\hline Averaging time (carcinogenic) & \multicolumn{2}{|l|}{$\mathrm{AT}_{\mathrm{C}}$} & days & 25,550 & & US EPA (1989) \\
\hline Conversion factor & $\mathrm{CF}$ & & $\mathrm{kg} / \mathrm{mg}$ & $1.00 \mathrm{E}-06$ & & US EPA (1989) \\
\hline Parameters & Symbol & & Units & Values & & Source \\
\hline Soil dermal exposure & & & & Children & Adults & \\
\hline Chemical concentration in soil & $\mathrm{C}_{\mathrm{S}}$ & & $\mathrm{mg} / \mathrm{kg}$ & site-specific & & This study \\
\hline Skin surface area** & SA & & $\mathrm{cm}^{2}$ & 5700 & 2800 & US EPA (2004) \\
\hline Soil to skin adherence factor & $\mathrm{AF}$ & & $\mathrm{mg} / \mathrm{cm}^{2}$ & 0.2 & 0.07 & US EPA (2004) \\
\hline Absorption factor for the skin & ABS & & unitless & 0.03 & & US EPA (2004) \\
\hline Exposure frequency & $\mathrm{EF}$ & & day/year & 100 & & This study \\
\hline Exposure duration & ED & & years & 6 & 30 & US EPA (2004) \\
\hline Body weight & BW & & $\mathrm{kg}$ & 15 & 70 & US EPA (1989) \\
\hline Averaging time (non-cancerogenic) & $\mathrm{AT}_{\mathrm{NC}}$ & & days & 2190 & 10,950 & US EPA (1989) \\
\hline Averaging time (carcinogenic) & $\mathrm{AT}_{\mathrm{C}}$ & & days & 25,550 & & US EPA (1989) \\
\hline Conversion factor & $\mathrm{CF}$ & & $\mathrm{kg} / \mathrm{mg}$ & $1.00 \mathrm{E}-03$ & & US EPA (1989) \\
\hline Parameters & Symbol & & Units & Values & & Source \\
\hline Water ingestion exposure & & & & Children & Adults & \\
\hline Element concentration in water & $\mathrm{C}_{\mathrm{W}}$ & & $\mathrm{mg} / \mathrm{l}$ & 0.35 & & Cinti et al. (2019) \\
\hline Ingestion rate of water & $\mathrm{IR}_{\mathrm{W}}$ & & 1/day & 0.12 & 0.5 & This study \\
\hline Exposure frequency & $\mathrm{EF}$ & & day/year & 100 & & This study \\
\hline Exposure duration & ED & & year & 6 & 30 & US EPA (2004) \\
\hline Body weight & $\mathrm{BW}$ & & year & 15 & 70 & US EPA (2004) \\
\hline Averaging time (non-cancerogenic) & $\mathrm{AT}_{\mathrm{NC}}$ & & days & 2190 & 10,950 & US EPA (1989) \\
\hline Averaging time (carcinogenic) & $\mathrm{AT}_{\mathrm{C}}$ & & days & 25,550 & & US EPA (1989) \\
\hline Parameters & & Symbol & Units & Values & & Source \\
\hline Water dermal exposure & & & & Children & Adults & \\
\hline Element concentration in water & & $\mathrm{C}_{\mathrm{W}}$ & $\mathrm{mg} / \mathrm{l}$ & 0.35 & & Cinti et al. (2019) \\
\hline Skin surface area & & SA & $\mathrm{cm}^{2}$ & 6600 & 18,000 & US EPA (2004) \\
\hline Chemical-specific dermal permeabilit & stant & $\mathrm{PC}$ & $\mathrm{cm} / \mathrm{h}$ & $1.00 \mathrm{E}-03$ & & GSI (2011) \\
\hline Exposure time $* * *$ & & ET & hours/day & 2.6 & & US EPA (1989) \\
\hline Exposure duration**** & & ED & years & 6 & 30 & US EPA (2004) \\
\hline Exposure frequency & & EF & day/year & 100 & & This study \\
\hline Body weight & & BW & $\mathrm{kg}$ & 15 & 70 & US EPA (2004) \\
\hline Averaging time (non-cancerogenic) & & $\mathrm{AT}_{\mathrm{NC}}$ & days & 2190 & 10,950 & US EPA (1989) \\
\hline
\end{tabular}


Table 3 continued

\begin{tabular}{lllll}
\hline $\begin{array}{l}\text { Parameters } \\
\text { Water dermal exposure }\end{array}$ & Symbol & Units & Values & Source \\
\cline { 3 - 5 } & & & Children & Adults \\
\hline Averaging time (carcinogenic) & $\mathrm{AT}_{\mathrm{C}}$ & days & 25,550 & US EPA (1989) \\
Volumetric conversion factor for water & $\mathrm{CF}_{\mathrm{W}}$ & $1 / \mathrm{cm}^{3}$ & $1.00 \mathrm{E}-03$ & US EPA (1989) \\
\hline$*$ Includes soil and outdoor settled dust & & & & \\
$* *$ Considered total body & & & & \\
$* * *$ For swimming & & &
\end{tabular}

(HQ), i.e., the potential for non-carcinogenic toxicity to occur, and the cancer risk (CR), i.e., the incremental probability of developing a cancer during a lifetime, refer to the threshold and non-threshold behavior, respectively. Skin cancer risk $\left(\mathrm{CR}_{\text {skin }}\right)$ was separately calculated for dermal and ingestion scenarios and for water and soil matrix. $\mathrm{HQ}$ and $\mathrm{CR}_{\text {skin }}$ were calculated as follows (US EPA, 2007a):

$$
\begin{aligned}
& \mathrm{HQ}=\frac{\mathrm{ADD} \times \mathrm{RBA}}{\mathrm{RfD}} \\
& C R_{\text {skin }}=L A D D \times R B A \times C S F
\end{aligned}
$$

where RfD is the oral reference dose of As for assessing non-cancer health effects $(0.0003 \mathrm{mg} /$ $\mathrm{kg} / \mathrm{day}$; US EPA, 1991) and CFS is the As cancer slope factor $(1.5 \mathrm{mg} / \mathrm{kg} /$ day for oral exposure; US EPA, 2010), while RBA is the relative bioaccessibility. For soils ingestion, RBA was specifically determined in this study at each studied point analyzed by SBET (Eq. 1; \$3.2.2) and not averaged (Izquierdo et al., 2015). For water ingestion, inorganic As is almost completely ( $\sim 95 \%$ ) adsorbed in the gastrointestinal tract (US EPA, 2004); consequently, a value of $100 \%$ of the ingested dose was set up in this study. For dermal contact, a dermal absorption rate of $1 \%$ was employed as suggested by Zuzolo et al. (2020). It has to be highlighted that US EPA did not define specific RfD and CSF for dermal exposure (US EPA, 2004); therefore, oral RfD and CFS are instead here employed. A systemic health risk is not expected when $\mathrm{HQ}<1$, while if HQ $>1$ there is a chance that non-carcinogenic effects may occur, with a probability which tends to increase as the value of $\mathrm{HI}$ increases (US EPA, 2001). For carcinogenic risk, acceptable or tolerable risk for US EPA regulatory purposes is in the range of $1 \times 10^{-6}$ and $1 \times 10^{-4}$ (i.e., 1 case of cancer in 1,000,000 exposed people to 1 case of cancer in 10,000 exposed people). The risk level of $1 \times 10^{-6}$ has been considered as the point of excess cancer risk, indicating 1 per 1,000,000 chance of getting cancer by single or multiple exposure routes. The safe point for carcinogenic risks must be lower than this level. Risks surpassing $1 \times 10^{-4}$ are unacceptable and need some sort of intervention and remediation.

Cumulative hazard quotient ( $\left.\mathrm{HQ}_{\mathrm{TOT}}\right)$ and cancer risk $\left(\mathrm{CR}_{\mathrm{TOT}}\right)$ were finally calculated assuming addition of adverse health effects for multiple exposure routes, i.e., $\mathrm{HQ}_{\mathrm{TOT}}=\sum_{n=1}^{i} \mathrm{HQ}_{i}$ and $\mathrm{CR}_{\text {skin, } \mathrm{TOT}}=$ $\sum_{n=1}^{i} \mathrm{CR}_{i}$

\section{Results}

Major chemistry and pseudo-total As

Travertines are mainly composed of $\mathrm{CaO}$ (mean $+\mathrm{s}-$ tandard deviation; $\left.\bar{x}_{\mathrm{CaO}}=54.06 \pm 1.76 \mathrm{wt} \%\right)$, with minor silica $\left(\mathrm{SiO}_{2} \leq 6.22 \mathrm{wt} \%\right)$ and $\mathrm{Fe}$ contents $\left(\mathrm{Fe}_{2} \mathrm{O}_{3} \leq 1.06 \mathrm{wt} \%\right.$ ) (Table S2). Al, Na, Mg, K, P, $\mathrm{Ti}$, and $\mathrm{Mn}$ oxides rarely exceed 1 weight $\%$ (Table S1). Fossil deposits show in general lower concentrations of $\mathrm{CaO}\left(\bar{x}_{\mathrm{CaO}}=52.57 \pm 1.92 \%\right)$ and higher contents of $\mathrm{Fe}_{2} \mathrm{O}_{3}\left(\bar{x}_{\mathrm{Fe} 2 \mathrm{O} 3}=0.43 \pm 0.43 \mathrm{wt} \%\right)$, $\mathrm{MnO}\left(\bar{x}_{\mathrm{MnO}}=0.12 \pm 0.13 \mathrm{wt} \%\right)$ and $\mathrm{SiO}_{2}\left(\bar{x}_{\mathrm{SiO} 2-}\right.$ $=2.89 \pm 2.41 \mathrm{wt} \%$ ) with respect to the new-forming ones $\quad\left(\bar{x}_{\mathrm{CaO}}=55.04 \pm 0.66 \quad \mathrm{wt} \% ; \quad \bar{x}_{\mathrm{Fe} 2 \mathrm{O} 3-}\right.$ $=0.06 \pm 0.04 \mathrm{wt} \% ; \bar{x}_{\mathrm{MnO}}=0.02 \pm 0.01 \mathrm{wt} \% ; \bar{x}_{\mathrm{SiO} 2}-$ $=0.78 \pm 0.41 \mathrm{wt} \%)$. 
Aging of travertine is hence indicated by crystallization of accessory minerals, such as $\mathrm{Fe}(\mathrm{Mn})$-oxydroxides, commonly associated with travertine deposits (e.g., Le Guern et al., 2003) and increased $\mathrm{SiO}_{2}$ content probably due to silicification of the deposits. Soils developed on both geological substrata (travertine and volcanic rocks) cover a wide range of $\mathrm{SiO}_{2}$ (31.75-55.02 wt\%), and $\mathrm{Al}_{2} \mathrm{O}_{3}$ (10.22-21.38 $\mathrm{wt} \%$ ) contents (Table S2). Soils formed on travertine are characterized by higher contents of $\mathrm{CaO}\left(\bar{x}_{\mathrm{CaO}}\right.$ $=11.12 \pm 9.74 \mathrm{wt} \%)$ compared to volcanic soils $\left(\bar{x}_{\mathrm{CaO}}=4.47 \pm 0.96 \mathrm{wt} \% ; \bar{x}_{\mathrm{LOI}}=7.54 \pm 0.96 \mathrm{wt} \%\right)$. On the contrary, volcanic soils show higher concentrations of $\mathrm{Fe}_{2} \mathrm{O}_{3}\left(\bar{x}_{\mathrm{Fe} 2 \mathrm{O} 3}=9.93 \pm 1.13 \mathrm{wt} \%\right), \mathrm{Na}_{2} \mathrm{O}$ $\left(\bar{x}_{\mathrm{Na} 2 \mathrm{O}}=1.00 \pm 0.17 \quad \mathrm{wt} \%\right)$ and $\mathrm{K}_{2} \mathrm{O} \quad\left(\bar{x}_{\mathrm{K} 2 \mathrm{O}-}\right.$ $=5.80 \pm 1.04 \mathrm{wt} \%)$ with respect to the carbonatic ones $\left(\bar{x}_{\mathrm{Fe} 2 \mathrm{O} 3}=7.84 \pm 1.46 \mathrm{wt} \% ; \quad \bar{x}_{\mathrm{Na} 2 \mathrm{O}}=0.45 \pm\right.$ $\left.0.21 \mathrm{wt} \% ; \bar{x}_{\mathrm{K} 2 \mathrm{O}}=2.97 \pm 0.46 \mathrm{wt} \%\right)$. Chemical characteristics of volcanic soils are consistent with the geochemistry of volcanic rocks belonging to the K-alkaline cycle of the Roman Magmatic Province (Conticelli et al., 2002). $\mathrm{CaO}$ (wt\%) concentrations reflect the variable content of calcite, which is the only carbonate mineral in soils (XRD data, not shown). Semi-quantitative estimates by XRD indicate that Bullicame soils (sample D03) are composed almost exclusively of calcite ( $>90 \mathrm{wt} \%$ ) with minor quartz and k-feldspar; however, calcite is minor at Piscine Carletti (sample D06) and in the agricultural areas, where silicate minerals (quartz, plagioclase, k-feldspar, and clay minerals) dominate. Here, minor $\mathrm{Fe}$ oxides (goethite) were also detected.

Arsenic in soils $\left(\mathrm{As}_{\mathrm{T}-2000}\right.$, referred simply as total As thereafter) ranges between 17 and $528 \mathrm{mg} / \mathrm{kg}$ (Table 1). Travertine and volcanic soils display mean total As of $197 \pm 127 \mathrm{mg} / \mathrm{kg}$ and $37 \pm 13 \mathrm{mg} / \mathrm{kg}$, respectively. Irrespective of the substratum, both soil types show higher As contents compared to As upper crustal range (2-5.7 mg/kg; Wedepohl, 1995; Hu \& Gao, 2008) and As in other geothermal manifestations in volcanic settings (Kusatsu, Japan: $15-170 \mathrm{mg} / \mathrm{kg}$, Kikawada et al., 2008; Bagno Vignoni, Mt. Amiata: 4.2-344 mg/kg Chiarantini et al., 2016). Similarly, travertine rocks display hundreds of $\mathrm{mg} / \mathrm{kg}$ of As (up to $276 \mathrm{mg} / \mathrm{kg}$ As; Table 1). Fossil travertines exhibit the greatest variability in As concentrations, ranging from 30 to $276 \mathrm{mg} / \mathrm{kg}$. In the sieved fraction $<250 \mu \mathrm{m}, \mathrm{As}_{\mathrm{T}-250}$ is comparable to $\mathrm{As}_{\mathrm{T}-2000}$ (differences ranging between 3 and 23\%).
SEC and SBET

Results of As extraction by SEC are shown in Table 4. Specific and non-specific exchangers (steps $\mathrm{A}_{\mathrm{SO} 4}$ and $\mathrm{A}_{\mathrm{PO} 4}$ ) extract moderate amounts of As (As $\leq 27 \mathrm{mg}$ / $\mathrm{kg}$ ) from new-forming travertine and fossil travertine deposits. Major differences between groups are observed in the other extraction steps. In the newforming travertine, the highest amounts of extracted As (128-162 mg/kg As) are observed in the carbonatic step $\left(\mathrm{A}_{\mathrm{CARB}}\right)$, while only $2-3 \mathrm{mg} / \mathrm{kg}$ As are associated with residual phases (A $\mathrm{A}_{\mathrm{OX}-\mathrm{SR}}^{\mathrm{SU}}$; Table 4$)$.

On the contrary, in fossil travertine, represented by sample VT9s, steps $A_{\mathrm{OX}}, A_{\mathrm{ox}+\mathrm{C}}$ and $A_{\mathrm{AR}}$ extract $169 \mathrm{mg} / \mathrm{kg}\left(\mathrm{A}_{\mathrm{OX}-\mathrm{AR}}^{\mathrm{SUM}}=169 \mathrm{mg} / \mathrm{kg}\right)$, with $66 \%$ of As extracted in the step dedicated to amorphous Fe oxides $\left(A_{\text {ox }}\right)$.

Sample VT7s shows an intermediate behavior between fossil and new-forming travertines, with the highest As concentration extracted from $\mathrm{A}_{\mathrm{CARB}}$ (35 mg/kg), but displaying higher As concentrations (up to $10 \mathrm{mg} / \mathrm{kg}$ ) from steps $A_{\mathrm{OX}}$ to $A_{\mathrm{AR}}$ compared to new-forming travertines.

In soils, As amounts recovered from the $\mathrm{A}_{\mathrm{SO} 4}$ in all samples are $<5 \mathrm{mg} / \mathrm{kg}$, while As ranges in the $\mathrm{A}_{\mathrm{PO} 4}$ fraction are of $10-46 \mathrm{mg} / \mathrm{kg}$. In all samples but D03 (Bullicame), As extracted from the carbonatic step is comprised in a narrow range of $10-20 \mathrm{mg} / \mathrm{kg}$, whereas the highest recovery is for the residual step (82-483 mg/kg) (Table 4). Notably, sample D03 is characterized by up to $141 \mathrm{mg} / \mathrm{kg}$ of $\mathrm{As}$ in the $\mathrm{A}_{\mathrm{CARB}}$ fraction, and low recovery in $\mathrm{A}_{\mathrm{AR}}(8 \mathrm{mg} / \mathrm{kg})$, comparable to travertine rocks.

Results of the bioaccessibility tests $\left(\mathrm{As}_{\mathrm{SBET}}\right.$ and RBA) are summarized in Fig. 2. Measured $\mathrm{As}_{\mathrm{SBET}}$ concentrations range from 24 to $139 \mathrm{mg} / \mathrm{kg} \mathrm{As}$, and in some cases, it nearly corresponds to $\mathrm{As}_{\mathrm{T}-250}$ concentrations, while RBA varied between 6 and $100 \%$. Major differences in $\mathrm{As}_{\mathrm{SBET}}$ concentrations and RBA are found among sampling sites. Soils from Bullicame show the highest $\mathrm{As}_{\mathrm{SBET}}(125-139 \mathrm{mg} / \mathrm{kg}$ ), corresponding to the highest relative bioaccessibility-RBA (80-100\%); lower bioaccessible values (24-93 mg/kg As) are otherwise observed in soils from Piscine Carletti, with RBA of 15-63\% (Fig. 2). It is important to note that the lowest percentages of RBA (7-27\%) are found in agricultural soils, which display the highest $\mathrm{As}_{\mathrm{T}}$ (130-528 mg/kg; Table 1). 
Table 4 Arsenic contents $(\mathrm{mg} / \mathrm{kg})$ extracted from SEC steps on soils and travertines

\begin{tabular}{|c|c|c|c|c|c|c|c|c|c|}
\hline Sample type & $\begin{array}{l}\text { Sample } \\
\text { ID }\end{array}$ & $\begin{array}{l}\mathrm{A}_{\mathrm{SO} 4-} \\
\left(\mathrm{A}_{\mathrm{SO} 4}{ }^{*}\right) \\
\mathrm{mg} / \mathrm{kg}\end{array}$ & $\begin{array}{l}\mathrm{A}_{\mathrm{PO} 4} \\
\left(\mathrm{~A}_{\mathrm{PO} 4} *\right)\end{array}$ & $\begin{array}{l}\mathrm{A}_{\mathrm{CARB}} \\
\left(\mathrm{A}_{\mathrm{CARB} *}\right)\end{array}$ & $\mathrm{A}_{\mathrm{OX}}$ & $\mathrm{A}_{\mathrm{OX}+\mathrm{C}}$ & $\begin{array}{l}\mathrm{A}_{\mathrm{AR}} \\
\left(\mathrm{A}_{\mathrm{AR}} *\right)\end{array}$ & ${ }_{\mathrm{AR}}^{\mathrm{A}_{\mathrm{OX}-}}$ & $\Sigma \mathrm{As}_{\mathrm{SEC}}$ \\
\hline \multirow{2}{*}{$\begin{array}{l}\text { New-forming } \\
\text { travertine }\end{array}$} & VT1s & 15 & 13 & 128 & 2 & $<\mathrm{DL}$ & $<\mathrm{DL}$ & 2 & 158 \\
\hline & VT6s & 4 & 17 & 162 & 1 & 1 & 1 & 3 & 186 \\
\hline \multirow[t]{2}{*}{ Fossil travertine } & VT7s & 2 & 8 & 35 & 10 & 1 & $<\mathrm{DL}$ & 11 & 56 \\
\hline & VT9s & 8 & 27 & 101 & 111 & 54 & 4 & 169 & 305 \\
\hline \multirow[t]{10}{*}{ Travertine soil } & D03 & 2 & 10 & 141 & nd & nd & 8 & nd & 161 \\
\hline & D06 & 3 & 14 & 18 & nd & nd & 218 & nd & 252 \\
\hline & D07 & 3 & 18 & 15 & nd & nd & 166 & nd & 202 \\
\hline & soilVT1 & 2 & 46 & 15 & 138 & 133 & 81 & 352 & 415 \\
\hline & soilVT2 & 2 & 45 & 11 & nd & nd & 442 & nd & 499 \\
\hline & soilVTB4 & 2 & 25 & 10 & nd & nd & 82 & nd & 119 \\
\hline & AS7 & 2 & 46 & 12 & nd & nd & 483 & nd & 543 \\
\hline & AS10 & 2 & 34 & 14 & nd & nd & 301 & nd & 351 \\
\hline & soilVT3 & 2 & 38 & 5 & 120 & 176 & 16 & 312 & 357 \\
\hline & soilVT4 & 2 & 7 & 19 & 31 & 20 & 75 & 126 & 154 \\
\hline
\end{tabular}

nd stands for not determined

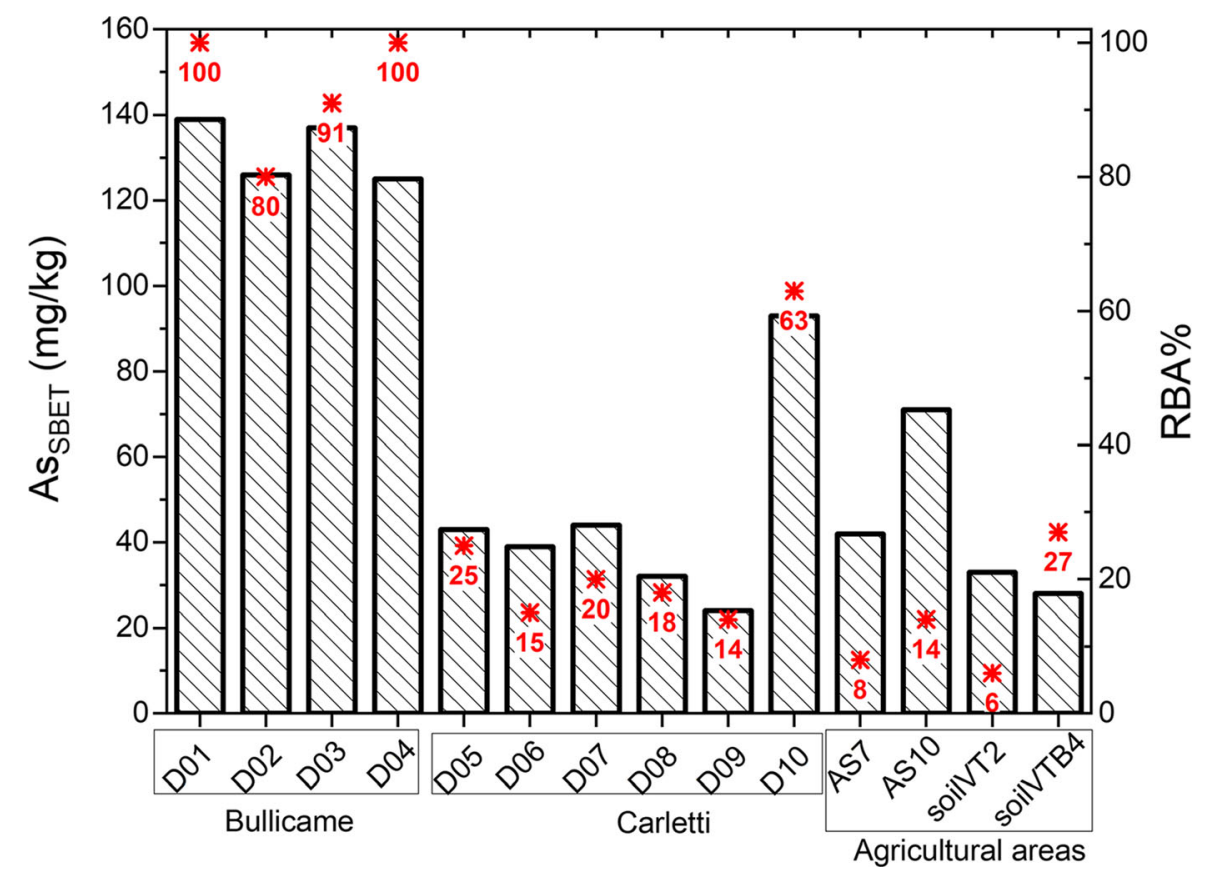

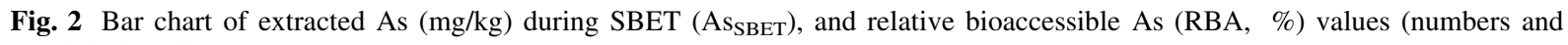
asterisks in red) 


\section{Discussion}

Arsenic source in soils of the Viterbo area

In the Viterbo area, a well-diffused geogenic As anomaly in groundwaters relates to the uprising of deep As-rich thermal waters (Angelone et al., 2009; Cinti et al., 2015, 2019; Vivona et al., 2007) that discharge at surface, precipitating travertine, dominantly composed by calcite ( $>94 \mathrm{wt} \%$ ) (Di Benedetto et al., 2011), and minor accessory phases $\left(\mathrm{Fe}_{2} \mathrm{O}_{3}\right.$, $\mathrm{TiO}_{2}, \mathrm{Al}_{2} \mathrm{O}_{3}$ and $\mathrm{MnO}$ rarely exceeding $1 \mathrm{wt} \%$ ). Arsenic repartition from solution to solid phase results in As enrichment in travertine, with up to $\sim 280 \mathrm{mg} /$ $\mathrm{kg}$ As found in fossil and new-forming deposits of the different plateau (Le Zitelle, Bullicame, and Piscine Carletti). Similar results were obtained by Dessau (1968), who documented up to $220 \mathrm{mg} / \mathrm{kg}$ of As in the travertine of Viterbo thermal springs (the exact location of the sampled spring is not given), and by Di Benedetto et al. (2011) in the travertine of Piscine Carletti spring (85-213 mg/kg As). Arsenic is often widespread in hot spring deposits (e.g., Webster and Nordstrom, 2003), but not many works investigated As in the associated travertine (Pentecost, 2005; Catelani et al., 2018). In addition to Costagliola et al. (2013), travertines with concentrations of As of hundreds to thousands $\mathrm{mg} / \mathrm{kg}$ were documented in Iran (Hamidian et al., 2019; Khorasanipour \& Esmaeilzadeh, 2015), Greece (Kampouroglou et al., 2017; Winkel et al., 2013), and Turkey (Dogan \& Dogan, 2007), commonly associated with tectonically active areas, where the waning stages of Quaternary volcanic activity set up hydrothermal circulation at a basin scale, vehiculating emissions of $\mathrm{CO}_{2}$-rich fluids to the surface (Minissale et al., 2002). High concentrations of $\mathrm{HCO}_{3}{ }^{-}$, as those commonly observed at the thermal pools of Viterbo (Duchi et al., 1985; Di Benedetto et al., 2011), may indeed favor the leaching of As from the rock pile, represented in the study area by volcanic rocks (Casentini et al., 2010), during the fluid ascent (Anawar et al., 2004). Concentrations of 9-166 mg/kg As were indeed documented in rocks of the VicanoCimino system (Armiento et al., 2015; Casentini et al., 2010), together with As-bearing mineral phases (Della Ventura et al., 1991).

Soils main geochemical characteristics strictly correlate with the nature of parent rock (travertine vs volcanite) (Table S2). Arsenic contents $\left(\mathrm{As}_{\mathrm{T}-2000}\right.$;
24-56 mg/kg), except in sample BLS7, far exceed the national accepted Italian threshold limit $(20 \mathrm{mg} / \mathrm{kg}$ ) for recreational and residential use soils (D.L. 152/06). Our results expand the dataset of Zuzolo et al. (2020), who reported maximum As concentrations of $60 \mathrm{mg} /$ $\mathrm{kg}$ in soils of the Viterbo area. Soils developed on travertines are particularly enriched in As when compared to those developed on the volcanic substratum (Mann-Whitney test, $p \ll 0.05$ ), suggesting that the As anomaly genetically relates to the formation of travertine plateau. For instance, the As is transferred to soils by dismantling the carbonate minerals.

Additional information on the processes controlling As distribution and partition in soils is provided by the sequential extraction procedures, specifically setup in this work to identify As speciation and leachability in samples characterized by high $\mathrm{CaO}$ contents. The carbonatic fraction hosts $81-88 \%$ of the total As (Fig. 3) in the new-forming travertines, and in soils at Bullicame (represented by sample D03), which are essentially a debris of the dismantled travertine rocks, and contain very abundant calcite (>90 wt $\%$ ). A specific and specifically sorbed As account for approximately $10 \%$ of the As budget, while the role of $\mathrm{Fe}(\mathrm{Mn})$-oxyhydroxides in As sorption is negligible $\left(\sim 1-5 \%\right.$ As is extracted in $\left.A_{A R}\right)$. On the contrary, at Piscine Carletti and in the agricultural areas, where soils are poor in calcite (silicates are dominant in the mineralogical analysis) and well-developed (thickness $\sim 50-60 \mathrm{~cm}$, with abundant vegetation), only minor As $(1-12 \%)$ is associated with the carbonate phase, and $\mathrm{Fe}(\mathrm{Mn})$-oxyhydroxides have the prominent role for As trapping (82-89\% of total As). It is worth to note that the $\mathrm{A}_{\mathrm{PO} 4}$ step accounts for up to $20 \%$ of the total As (Fig. 3), suggesting that the common employment of phosphate-based fertilizers in agricultural terrain may likely induce As mobilization from the soils due to the competitive $\mathrm{PO}_{4}{ }^{3-}$ for $\mathrm{AsO}_{4}{ }^{3-}$ exchange (Zeng et al., 2008). Fossil travertines collocate between the two end-members (i.e., highand low-calcite soils), displaying intermediate percentage of As bound to calcite (33-63\%; Fig. 3).

Iron oxides are well-known scavengers of As in the environment by establishing inner- and outer-sphere surface complexes (Giménez et al., 2007; Goldberg \& Johnston, 2001), as well as As incorporation in the lattice structure. Besides Fe(hydr)oxides, laboratory experiments demonstrated that calcite efficiently retains As by surficial adsorption mechanisms (Sø 


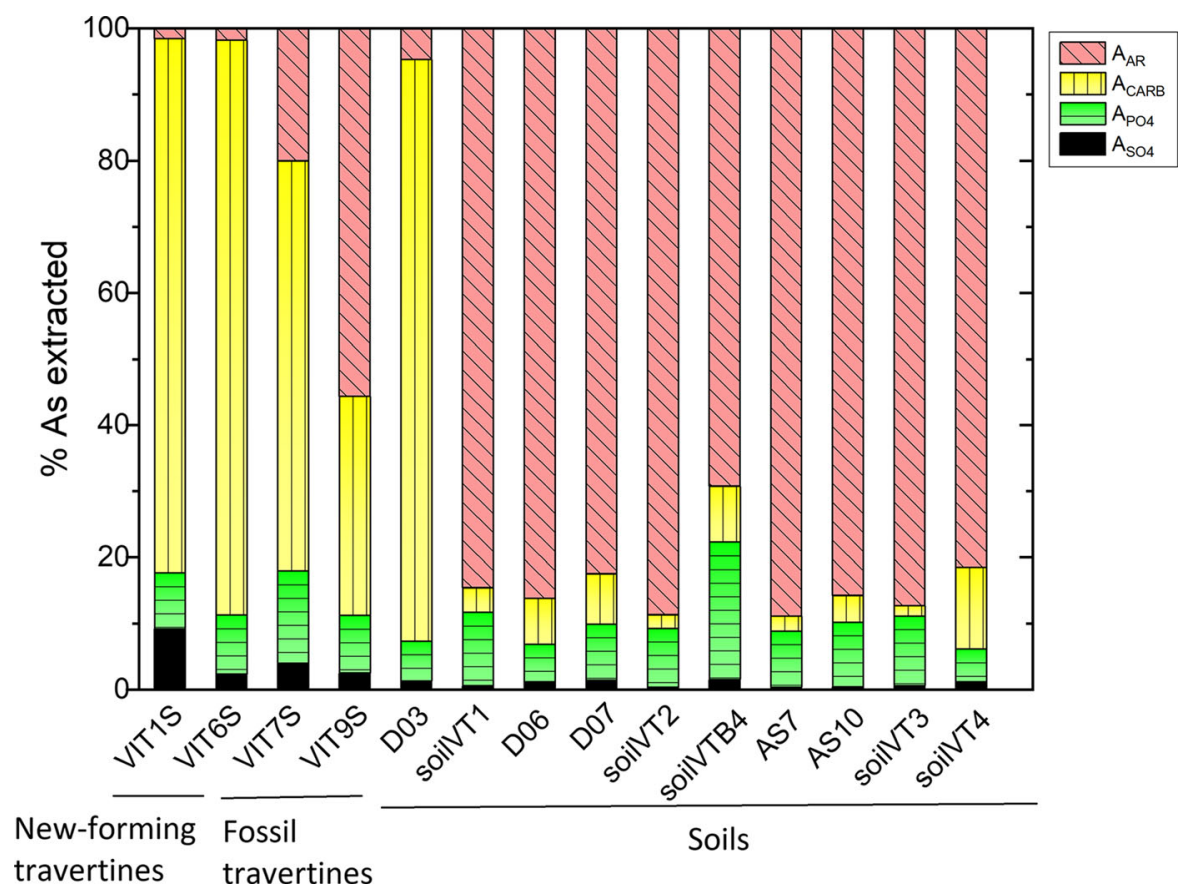

Fig. 3 Percentages (normalized to $100 \%$ of extraction) of extracted As by SEC

et al., 2008) and/or structural incorporation (Alexandratos et al., 2007; Yokoyama et al., 2009, 2012). In natural travertines, $\mathrm{As}(\mathrm{III})$ can be incorporated in calcite through the substitution of $\mathrm{AsO}_{3}{ }^{3-}$ for $\mathrm{CO}_{3}{ }^{2-}$ (Bardelli et al., 2011; Di Benedetto et al., 2006). Recently, As $(\mathrm{V})$ has been documented in the crystal lattice of calcite precipitating at Bullicame, while both $\mathrm{As}(\mathrm{V})$ and $\mathrm{As}(\mathrm{III})$ species were observed in biogenic calcites produced by the As-resistant bacterium $B$. Licheniformis, synthesized under laboratory condition on a solid medium (Catelani et al., 2018).

Data show that As-rich calcite dissolution from travertine likely controls As translocation in natural soils of the Viterbo area. Surface dissolution of calcite occurs during travertine diagenesis, when rocks are exposed to percolation of solutions undersaturated with respect to the carbonatic mineral, such as direct rainfall (Pentecost, 2005), and it is accompanied by $\mathrm{Fe}(\mathrm{Mn})-$ enrichment, likely suggesting $\mathrm{Fe}-\mathrm{Mn}$ (hydr)oxides deposition. This is confirmed by major chemistry analysis of the fossil rocks, displaying lower $\mathrm{CaO}$ wt\% and higher $\mathrm{Fe}_{2} \mathrm{O}_{3}$ and $\mathrm{MnO}$ wt $\%$ with respect to the travertine mud, and by SEC results showing progressively lower As recovery (both as absolute and percentage values) from the carbonatic step with increasing travertine age (Table 4; Fig. 3).
In conclusion, at Viterbo, calcite acts indeed only as a short-term trap for As, which is released by dissolution of the primary host, and finally transferred to Fe oxy(hydr)oxides during pedogenesis.

Arsenic bioaccessibility and estimation of health risk

In the Viterbo soils, As is distributed in different solid phases, which have different As bioaccessibility. Differently from other studies which found a linear correlation between bioaccessible concentrations of As and total concentrations in the soils (Hiller et al., 2018), total As contents in the studied soils are not explicative of As bioaccessibility (Fig. 4), which depends on the As mineral hosting phase. Relative bioaccessibility is variable among the investigated sites, reaching $80-100 \%$ in soils at Bullicame, and lowering to $6-63 \%$ at Piscine Carletti and in the agricultural areas (Fig. 2). It is our opinion that bioaccessibility is related to the presence of calcite, which easily dissolves in the gastric conditions simulated by the in vitro test. However, we suggest the opportunity of further investigations to increase the sampling number and to perform statistically significant tests. 


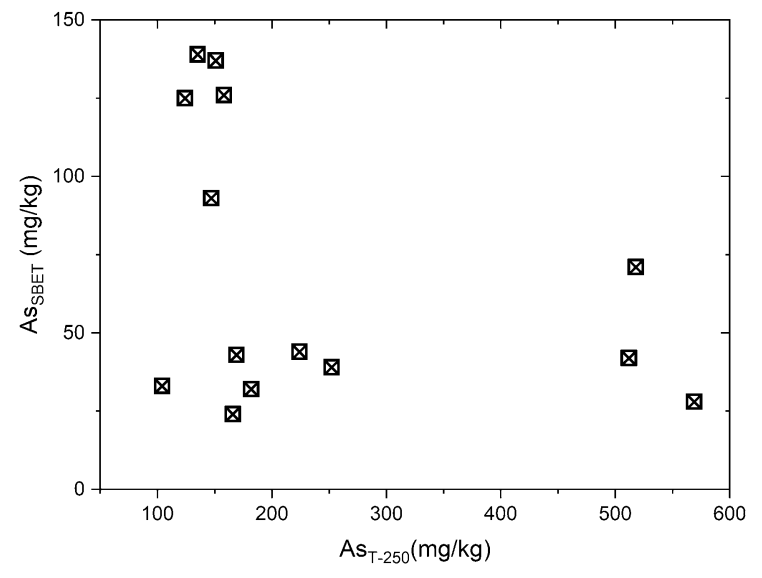

Fig. 4 Bivariate plot showing (pseudo) total As in the $250 \mu \mathrm{m}$ fraction $\left(\mathrm{As}_{\mathrm{T}-250}, \mathrm{mg} / \mathrm{kg}\right)$ and absolute bioaccessible As $\left(\mathrm{As}_{\mathrm{SBET}}, \mathrm{mg} / \mathrm{kg}\right)$

The ranges of RBA of Bullicame soils are the highest documented in literature for soils where As bioaccessibility was determined by SBET. For example, up to $56.1 \%$ RBA was reported in playground soils of Bratislava, Slovakia (Hiller et al., 2018), or 46.3\% in residential soils of Ambagarh Chowki block, India (Das et al., 2013). Significantly lower RBA was also documented in mine-impacted soils due to the presence of arsenopyrite and complex ferric arsenates, both hardly soluble in simulated gastric conditions (Drahota et al., 2017; Gamiño-Gutiérrez et al., 2013; Li et al., 2015). Similar to our study, high RBA
( $\sim 80 \%$ ) was observed in the playground soils of Madrid, where the presence of easily dissolved carbonate was hypothesized (Mingot et al., 2011), hence confirming the prominent role of carbonate minerals in controlling As bioavailability.

In this study, we specifically estimate the daily As intake, and the associated carcinogenic (CR) and noncarcinogenic (HQ) risks via ingestion of soils for different age groups of people (children and adults). Furthermore, other potentially relevant sources of As exposures connected to the thermal pools attendance are evaluated, like the As adsorption by dermal contact with soil and water, and thermal water ingestion for depurative purposes. The overall risk associated with the multiple exposure pathways is also evaluated. Data are summarized in Table 5.

Based on the $\mathrm{CR}_{\text {skin,TOT, the additional chance of }}$ developing a skin cancer during the lifetime due to the overall As exposure routes is in the range of $1.0-1.1 \times 10^{-4}$ and $4.5-4.7 \times 10^{-4}$ (Table 5) for children and adults, respectively. These values denote a potential high risk for population visiting the thermal pools, exceeding both the US EPA and Italian jurisdiction values of one additional case of cancer in one-million $\left(1 \times 10^{-6}\right)$, which is used as a management goal for the risks posed by environmental contaminants. In detail, dermal exposure scenarios derived from water and soil contact are lower than the safer point (i.e., $\quad \mathrm{CR}_{\text {skin, TOT }}=1 \times 10^{-6}$ ), being around $10^{-7}-10^{-8}$ (Table 5), likely due to the low

Table 5 Results of the computed hazard quotient $(\mathrm{HQ})$ and cancer risk $\left(\mathrm{CR}_{\text {skin }}\right)$ for different age groups and exposure pathways with respect to thermal water and soil

\begin{tabular}{|c|c|c|c|c|c|c|c|c|c|}
\hline \multirow[t]{2}{*}{ Sample type } & \multirow[t]{2}{*}{ Exposure pathway } & \multicolumn{4}{|l|}{ HQ } & \multicolumn{4}{|l|}{$\mathrm{CR}_{\text {skin }}$} \\
\hline & & Children & & Adults & & Children & & Adults & \\
\hline \multirow{2}{*}{$\begin{array}{c}\text { Thermal } \\
\text { water }\end{array}$} & Ingestion & 2.6 & $(88 \%)$ & $\underline{2.3}$ & $(99 \%)$ & $9.9 \mathrm{E}-05$ & $(88 \%)$ & $\underline{4.5 \mathrm{E}-04}$ & $(97 \%)$ \\
\hline & Dermal contact & $\overline{3.7} \mathrm{E}-03$ & $(0 \%)$ & $\overline{2.1} \mathrm{E}-03$ & $(0 \%)$ & $\overline{1.4 \mathrm{E}-07}$ & $(0 \%)$ & $\overline{1.4 \mathrm{E}-07}$ & $(0 \%)$ \\
\hline \multirow[t]{6}{*}{ Soil } & Ingestion (min-max) & $5.8 \mathrm{E}-02$ & $(12 \%)$ & $3.1 \mathrm{E}-03$ & $(1 \%)$ & $2.3 \mathrm{E}-06$ & $(12 \%)$ & $2.7 \mathrm{E}-06$ & $(3 \%)$ \\
\hline & & $3.3 \mathrm{E}-01$ & & $1.8 \mathrm{E}-02$ & & $\underline{1.3 \mathrm{E}-05}$ & & $1.6 \mathrm{E}-05$ & \\
\hline & Dermal contact (min- & $2.2 \mathrm{E}-03$ & $(0 \%)$ & $8.0 \mathrm{E}-05$ & $(0 \%)$ & $8.4 \mathrm{E}-08$ & $(0 \%)$ & $1.2 \mathrm{E}-08$ & $(0 \%)$ \\
\hline & $\max )$ & $1.2 \mathrm{E}-02$ & & $4.4 \mathrm{E}-04$ & & $4.6 \mathrm{E}-07$ & & $6.7 \mathrm{E}-08$ & \\
\hline & $\mathrm{HQ}_{\mathrm{TOT}}$ & $\underline{2.7-2.9}$ & & $\underline{2.3}$ & & - & & - & \\
\hline & $\mathrm{CR}_{\text {skin,TOT }}$ & - & & - & & $\underline{1.0-1.1 \mathrm{E}-04}$ & & $\underline{4.5-4.7 \mathrm{E}-04}$ & \\
\hline
\end{tabular}

Double underlined numbers identify high carcinogenic and/or systemic risk $\left(\mathrm{CR}_{\text {skin }}>1 \times 10^{-4}\right.$ or $\left.\mathrm{HQ}>1\right)$, while single underlined numbers indicate situation with moderate risk $\left(\mathrm{CR}_{\text {skin }}>1 \times 10^{-5}\right)$. Percentages refer to the contribution of the exposure risk (HQ or $\mathrm{CR})$ due to a single pathway scenario with respect to the total $\left(\mathrm{HQ}_{\mathrm{TOT}}, \mathrm{CR}_{\text {skin, тот }}\right)$ 
absorption of As through the skin. On the contrary, water ingestion is evidently the most relevant exposure route, accounting for $88-97 \%$ (Table 5) of the total $\mathrm{CR}_{\text {skin }}$ risk for children and adults, respectively. In the light of these data, consumption of thermal waters for depurative purposes, commonly practiced by local residents, should be strongly discouraged. On the other hand, As exposure due to soil ingestion is not entirely negligible, since it shows a moderate cancer risk for children $\left(\mathrm{CR}_{\text {skin }}=1.3 \times 10^{-5}\right)$ and adults $\left(1.5 \times 10^{-5}\right)$. This is especially relevant for children (12\% of total cancer risk) due to the common mouthto-hands activity during outdoor playing. Accordingly, the geographical distribution of As-related cancer risk due to soil ingestion highlights a moderate risk $\left(1 \times 10^{-5}-1 \times 10^{-6}\right)$ in Italian central regions, like Latium (Zuzolo et al., 2020), as a consequence of geogenic As anomalies occurring in water and soils. In their work, Zuzolo et al. (2020) did not take into consideration bioaccessibility for risk calculation. However, we stress that it is a crucial step in exposure and risk analysis (US EPA, 2007a). The proposed method allows identifying the area at Bullicame as the one with the highest $\left(1.1-1.5 \times 10^{-5}\right)$ cancer health risk, due to RBA approaching $100 \%$ of the total As budget in soils (Fig. 2).

The determined values of hazard quotient (HQ) indicate that As concentrations in soils via dermal or ingestion pathways or in water by dermal contact do not result in higher likelihood of non-carcinogenic health effects for people visiting the recreational thermal areas of Viterbo (HQ $<1$; Table 5). However, a significant potential health risk (HQ = 2.3-2.6) for pathologies such as hyperpigmentation, keratosis, and possible vascular complications, associated with chronic exposure to As, occurs through thermal water ingestion.

Similarly, the lifetime consumption of As-contaminated tap water in the Viterbo region potentially exposes people to high skin cancer risk $\left(1 * 10^{-4}-10^{-3}\right)$ and hazard risk $(\mathrm{HQ}=4)$ (Zuzolo et al., 2020).

\section{Conclusions}

Travertine and soils developed on volcanic and travertine substratum are investigated for As contents in and around the two most famous hot springs near Viterbo (Bullicame and Piscine Carletti), which host urban recreational areas highly frequented by local population and tourists. A wide geogenic As anomaly affecting both fossil and recently formed travertine is documented. In soils, As concentrations (42-528 mg/ $\mathrm{kg}$ ) largely exceeding Italian law limits spatially and genetically relate to the underlying travertine plateau. Sequential extractions and bioaccessibility test (SBET) are employed to elucidate the mineral phases controlling As bioaccessibility, and the processes that govern As distribution in the environment. SEC data indicate that in travertines and poorly developed soils, calcite is the primary mineral phase containing As (33-88\% of the total As budget), while in welldeveloped soils As is mainly bound to Fe oxy(hydr)oxides (calcite only entrapped $1-12 \%$ of total As). Arsenic-rich calcite dissolution from new-forming travertine during diagenesis and pedogenesis is responsible for As partition in local soils and subsequent transfer to Fe oxy(hydr)oxides. Arsenic relative bioaccessibility is especially elevated in soils of the Bullicame area (80-100\%), likely due to the presence of calcite, which is highly soluble in human gastric conditions, while it is low in agricultural soils (6-27\%), where $\mathrm{Fe}$ oxy(hydr)oxides dominate. Arsenic exposure scenarios and associated risk analysis indicate that a moderate carcinogenic risk $\left(\mathrm{CR}_{\text {skin }}>1 \times 10^{-5}\right)$ is present for adults and children by soil ingestion pathway. Nonetheless, the ingestion of contaminated water remains the principal exposure route for people attending the thermal pools. Therefore, we strongly suggest providing the thermal parks with public informative plaques discouraging people on the habit of thermal waters consumption.

Acknowledgements Most data presented here were obtained during the training periods or thesis works (Laurea in Scienze Geologiche) of A. Ciardi, D. Del Soldato, A. Sacco. Authors gratefully acknowledge the work of these students. Assistance of P. Parrini and E. Pecchioni with XRD and XRF analyses is gratefully acknowledged. We gratefully acknowledge the constructive criticism by three anonymous reviewers.

Authors' contributions PC and VR conceived and designed the study; VR, PC, PL and TC conducted the field campaigns; VR and MP performed the analysis; TC contributed data or analysis tool; VR wrote the original manuscript draft; PC, PL, GM, DM and SF integrated the draft; VR and SF took care of the paper graphs and images.

Funding Open access funding provided by Università degli Studi di Firenze within the CRUI-CARE Agreement. The work 
was financially supported by Italian ordinary university funds grant to Pilario Costagliola.

Availability of data and material All data generated or analyzed during this study are included in this published article (and its supplementary information files). All data generated or analyzed during this study are included in this published article (and its supplementary information files).

\section{Declaration}

Conflict of interest The authors declare that they have no conflict of interest.

Open Access This article is licensed under a Creative Commons Attribution 4.0 International License, which permits use, sharing, adaptation, distribution and reproduction in any medium or format, as long as you give appropriate credit to the original author(s) and the source, provide a link to the Creative Commons licence, and indicate if changes were made. The images or other third party material in this article are included in the article's Creative Commons licence, unless indicated otherwise in a credit line to the material. If material is not included in the article's Creative Commons licence and your intended use is not permitted by statutory regulation or exceeds the permitted use, you will need to obtain permission directly from the copyright holder. To view a copy of this licence, visit http://creativecommons.org/licenses/by/4.0/.

\section{References}

Alexandratos, V. G., Elzinga, E. J., \& Reeder, R. J. (2007). Arsenate uptake by calcite: Macroscopic and spectroscopic characterization of adsorption and incorporation mechanisms. Geochimica et Cosmochimica Acta, 71(17), 4172-4187. https://doi.org/10.1016/j.gca.2007.06.055

Anawar, H. M., Akai, J., \& Sakugawa, H. (2004). Mobilization of arsenic from subsurface sediments by effect of bicarbonate ions in groundwater. Chemosphere, 54(6), 753-762. https://doi.org/10.1016/j.chemosphere.2003.08. 030

Angelone, M., Cremisini, C., Piscopo, V., Proposito, M., \& Spaziani, F. (2009). Influence of hydrostratigraphy and structural setting on the arsenic occurrence in groundwater of the Cimino-Vico volcanic area (central Italy). Hydrogeology Journal, 17(4), 901-914. https://doi.org/10.1007/ s10040-008-0401-3

Appleton, J. D., Cave, M. R., \& Wragg, J. (2012). Anthropogenic and geogenic impacts on arsenic bioaccessibility in UK topsoils. Science of the Total Environment, 435-436, 21-29. https://doi.org/10.1016/j.scitotenv.2012.07.002

Armiento, G., Baiocchi, A., Cremisini, C., Crovato, C., Lotti, F., Lucentini, L., et al. (2015). An integrated approach to identify water resources for human consumption in an area affected by high natural arsenic content. Water, 7(9), 5091-5114. https://doi.org/10.3390/w7095091
Bagherifam, S., Lakzian, A., Fotovat, A., Khorasani, R., \& Komarneni, S. (2014). In situ stabilization of As and Sb with naturally occurring $\mathrm{Mn}, \mathrm{Al}$ and Fe oxides in a calcareous soil: Bioaccessibility, bioavailability and speciation studies. Journal of Hazardous Materials, 273, 247-252. https://doi.org/10.1016/j.jhazmat.2014.03.054

Baiocchi, A., Lotti, F., \& Piscopo, V. (2012). Conceptual hydrogeological model and groundwater resource estimation in a complex hydrothermal area: The case of the Viterbo geothermal area (Central Italy). Journal of Water Resource and Protection, 04(04), 231-247. https://doi.org/ 10.4236/jwarp.2012.44026

Barberi, F., Buonasorte, G., Cioni, R., Fiordelisi, A., Foresi, L., Iaccarino, S., et al. (1994). Plio-Pleistocene geological evolution of the geothermal area of Tuscany and Latium. Memorie Descrittive della Carta Geologica d'Italia, 49, 77-134.

Bardelli, F., Benvenuti, M., Costagliola, P., Di Benedetto, F., Lattanzi, P., Meneghini, C., et al. (2011). Arsenic uptake by natural calcite: An XAS study. Geochimica et Cosmochimica Acta, 75(11), 3011-3023. https://doi.org/10. 1016/j.gca.2011.03.003

Benvenuti, M. G., Benvenuti, R., Costagliola, P., \& Tanelli, G. (2009). Quaternary evolution of the pecora river (southern tuscany, Italy): Paleohydrography and sediments provenance. Bollettino Della Societa Geologica Italiana, 128(1), 61-72.

Bradham, K. D., Diamond, G. L., Burgess, M., Juhasz, A., Klotzbach, J. M., Maddaloni, M., et al. (2018). In vivo and in vitro methods for evaluating soil arsenic bioavailability: Relevant to human health risk assessment. Journal of Toxicology and Environmental Health, Part B, 21(2), 83-114. https://doi.org/10.1080/10937404.2018.1440902

Calabrese, E. J., Barnes, R., Stanek, E. J., III, Pastides, H., Gilbert, C. E., Veneman, P., et al. (1989). How much soil do young children ingest: An epidemiologic study. Regulatory Toxicology and Pharmacology, 10(2), 123-137. https://doi.org/10.1016/0273-2300(89)90019-6

Casentini, B., Pettine, M., \& Millero, F. J. (2010). Release of arsenic from volcanic rocks through interactions with inorganic anions and organic ligands. Aquatic Geochemistry, 16(3), 373-393. https://doi.org/10.1007/s10498-0109090-3

Catelani, T., Perito, B., Bellucci, F., Lee, S. S., Fenter, P., Newville, M., et al. (2018). Arsenic uptake in bacterial calcite. Geochimica et Cosmochimica Acta, 222, 642-654. https://doi.org/10.1016/j.gca.2017.11.013

Cave, M., Wragg, J., Palumbo, B., \& Klinck, B. A. (2003). Measurement of the bioaccessibility of arsenic in UK soils. Isbn. http://a0768b4a8a31e106d8b050dc802554eb38a24458b98ff72d550b.r19.cf3.rackcdn. com/sp5-062-tr-2-e-e.pdf

Chiarantini, L., Benvenuti, M., Beutel, M., Costagliola, P., Covelli, S., Gabbani, G., et al. (2016). Mercury and arsenic in stream sediments and surface waters of the Orcia River basin, southern Tuscany, Italy. Water, Air, and Soil Pollution, 227(11), 1-15. https://doi.org/10.1007/s11270-0163110-x

Cinti, D., Poncia, P. P., Brusca, L., Tassi, F., Quattrocchi, F., \& Vaselli, O. (2015). Spatial distribution of arsenic, uranium and vanadium in the volcanic-sedimentary aquifers of the 
Vicano-Cimino Volcanic District (Central Italy). Journal of Geochemical Exploration, 152, 123-133. https://doi. org/10.1016/j.gexplo.2015.02.008

Cinti, D., Vaselli, O., Poncia, P. P., Brusca, L., Grassa, F., Procesi, M., et al. (2019). Anomalous concentrations of arsenic, fluoride and radon in volcanic-sedimentary aquifers from central Italy: Quality indexes for management of the water resource. Environmental Pollution, 253, 525-537. https://doi.org/10.1016/j.envpol.2019.07.063

Conticelli, S., D’Antonio, M., Pinarelli, L., \& Civetta, L. (2002). Source contamination and mantle heterogeneity in the genesis of Italian potassic and ultrapotassic volcanic rocks: $\mathrm{Sr}-\mathrm{Nd}-\mathrm{Pb}$ isotope data from Roman Province and Southern Tuscany. Mineralogy and Petrology, 74(2-4), 189-222. https://doi.org/10.1007/s007100200004

Costagliola, P., Bardelli, F., Benvenuti, M., Di Benedetto, F., Lattanzi, P., Romanelli, M., et al. (2013). Arsenic-bearing calcite in natural travertines: Evidence from sequential extraction, $\mu \mathrm{XAS}$, and $\mu \mathrm{XRF}$. Environmental Science and Technology, 47(12), 6231-6238. https://doi.org/10.1021/ es304953a

Costagliola, P., Benvenuti, M. M., Benvenuti, M. G., Di Benedetto, F., \& Lattanzi, P. (2010). Quaternary sediment geochemistry as a proxy for toxic element source: A case study of arsenic in the pecora valley (southern tuscany, Italy). Chemical Geology, 270(1-4), 80-89. https://doi.org/ 10.1016/j.chemgeo.2009.11.007

Dani, S. U. (2010). Arsenic for the fool: An exponential connection. Science of the Total Environment, 408(8), 1842-1846. https://doi.org/10.1016/j.scitotenv.2010.01. 027

Das, S., Jean, J. S., \& Kar, S. (2013). Bioaccessibility and health risk assessment of arsenic in arsenic-enriched soils, Central India. Ecotoxicology and Environmental Safety, 92, 252-257. https://doi.org/10.1016/j.ecoenv.2013.02.016

Della Vedova, B., Bellani, S., Pellis, G., \& Squarci, P. (2001). Deep temperatures and surface heat flow distribution. In Anatomy of an orogen: The Apennines and adjacent Mediterranean basins (pp. 65-76). Springer, Dordrecht.

Della Ventura, G., Maras, A., Mottana, A., Parodi, G. C., Sacerdoti, M., \& Stoppani, F. S. (1991). Antimonian asbecasite in a syenitic ejectum within the Vico pyroclastic rocks (Roman potassic province). Rendiconti Lincei, 2(4), 371-378.

Dessau, G. (1968). Il berillio e l'arsenico nei travertini dell'Italia Centrale. Atti Società Toscana Scienze Naturali, 75, 690-711.

Di Benedetto, F., Costagliola, P., Benvenuti, M., Lattanzi, P., Romanelli, M., \& Tanelli, G. (2006). Arsenic incorporation in natural calcite lattice: Evidence from electron spin echo spectroscopy. Earth and Planetary Science Letters, 246(3-4), 458-465. https://doi.org/10.1016/j.eps1.2006.03. 047

Di Benedetto, F., Montegrossi, G., Minissale, A., Pardi, L. A., Romanelli, M., Tassi, F., et al. (2011). Biotic and inorganic control on travertine deposition at Bullicame 3 spring (Viterbo, Italy): A multidisciplinary approach. Geochimica et Cosmochimica Acta, 75(16), 4441-4455. https://doi.org/ 10.1016/j.gca.2011.05.011

D.L. 152/2006 (Legislative Decree 2006 n.15) "Norme in materia ambientale". Gazzetta Ufficiale n. 88 14-4-2006,
Suppl Ord n. 96; http://www.camera.it/parlam/leggi/ deleghe/06152dl.htm

Dogan, M., \& Dogan, A. U. (2007). Arsenic mineralization, source, distribution, and abundance in the Kutahya region of the western Anatolia, Turkey. Environmental Geochemistry and Health, 29(2), 119-129. https://doi.org/10. 1007/s10653-006-9071-z

Drahota, P., Raus, K., Rychlíková, E., \& Rohovec, J. (2017). Bioaccessibility of $\mathrm{As}, \mathrm{Cu}, \mathrm{Pb}$, and $\mathrm{Zn}$ in mine waste, urban soil, and road dust in the historical mining village of Kaňk, Czech Republic. Environmental Geochemistry and Health, 40(4), 1495-1512. https://doi.org/10.1007/s10653-0179999-1

Duchi, V., Minissale, A., \& Romani, L. (1985). Studio geochimico su acque e gas dell'area geotermica lago diVico-M.Cimini (Viterbo). Atti della Societa Toscana di Scienze Naturali Residente in Pisa, Memorie, Processi Verbali, Serie A, 92, 237-254. (in Italian).

Epa, U. S. (1991). IRIS Summary Chemical assessment summary of inorganic Arsenic (Cancer). U.S. Environmental Protection Agency.

Franzini, M., Leoni, M., \& Saitta, M. (1975). Revisione di una metodologia analitica per fluorescenza-X, basata sulla correzione completa degli effetti di matrice. Rendiconti Società Italiana di Mineralogia e Petrologia, 31(2), 365-378.

Gamiño-Gutiérrez, S. P., González-Pérez, C. I., Gonsebatt, M. E., \& Monroy-Fernández, M. G. (2013). Arsenic and lead contamination in urban soils of Villa de la Paz (Mexico) affected by historical mine wastes and its effect on children's health studied by micronucleated exfoliated cells assay. Environmental Geochemistry and Health, 35(1), 37-51. https://doi.org/10.1007/s10653-012-9469-8

Giménez, J., Martínez, M., de Pablo, J., Rovira, M., \& Duro, L. (2007). Arsenic sorption onto natural hematite, magnetite, and goethite. Journal of Hazardous Materials, 141(3), 575-580. https://doi.org/10.1016/j.jhazmat.2006.07.020

Girouard, E., \& Zagury, G. J. (2009). Arsenic bioaccessibility in CCA-contaminated soils: Influence of soil properties, arsenic fractionation, and particle-size fraction. Science of the Total Environment, 407(8), 2576-2585. https://doi.org/ 10.1016/j.scitotenv.2008.12.019

Goldberg, S., \& Johnston, C. T. (2001). Mechanisms of arsenic adsorption on amorphous oxides evaluated using macroscopic measurements, vibrational spectroscopy, and surface complexation modeling. Journal of Colloid and Interface Science, 234(1), 204-216. https://doi.org/10. 1006/jcis.2000.7295

GSI. (2011). Chemical database for arsenic. https://www.gsinet.com/en/publications/gsi-chemical-database/single/34arsenic.html

Hamidian, A. H., Razeghi, N., Zhang, Y., \& Yang, M. (2019). Spatial distribution of arsenic in groundwater of Iran, a review. Journal of Geochemical Exploration, 201(March), 88-98. https://doi.org/10.1016/j.gexplo.2019.03.014

Hiller, E., Filová, L., Jurkovič, L., Lachká, L., Kulikova, T., \& Šimurková, M. (2018). Arsenic in playground soils from kindergartens and green recreational areas of Bratislava City (Slovakia): Occurrence and gastric bioaccessibility. Archives of Environmental Contamination and Toxicology, 
75(3), 402-414. https://doi.org/10.1007/s00244-018-0534$\mathrm{x}$

Hu, Z., \& Gao, S. (2008). Upper crustal abundances of trace elements: A revision and update. Chemical Geology, 253(3-4), 205-221. https://doi.org/10.1016/j.chemgeo. 2008.05.010

Hu, X., Zhang, Y., Luo, J., Wang, T., Lian, H., \& Ding, Z. (2011). Bioaccessibility and health risk of arsenic, mercury and other metals in urban street dusts from a mega-city, Nanjing, China. Environmental Pollution, 159(5), 1215-1221. https://doi.org/10.1016/j.envpol.2011.01.037

Izquierdo, M., De Miguel, E., Ortega, M. F., \& Mingot, J. (2015). Bioaccessibility of metals and human health risk assessment in community urban gardens. Chemosphere, 135, 312-318. https://doi.org/10.1016/j.chemosphere. 2015.04.079

Juhasz, A. L., Herde, P., Herde, C., Boland, J., \& Smith, E. (2014). Validation of the predictive capabilities of the Sbrc-G in vitro assay for estimating arsenic relative bioavailability in contaminated soils. Environmental Science and Technology, 48(21), 12962-12969. https://doi. org/10.1021/es503695g

Juhasz, A. L., Smith, E., Weber, J., Rees, M., Rofe, A., Kuchel, T., et al. (2007). In vitro assessment of arsenic bioaccessibility in contaminated (anthropogenic and geogenic) soils. Chemosphere, 69(1), 69-78. https://doi.org/10.1016/ j.chemosphere.2007.04.046

Kampouroglou, E. E., Tsikos, H., \& Economou-Eliopoulos, M. (2017). Carbonate stable isotope constraints on sources of arsenic contamination in Neogene tufas and travertines of Attica, Greece. Open Geosciences, 9(1), 577-592. https:// doi.org/10.1515/geo-2017-0043

Karna, R. R., Noerpel, M., Betts, A. R., \& Scheckel, K. G. (2017). Lead and arsenic bioaccessibility and speciation as a function of soil particle size. Journal of Environmental Quality, 46(6), 1225-1235. https://doi.org/10.2134/ jeq2016.10.0387

Khorasanipour, M., \& Esmaeilzadeh, E. (2015). Geo-genic arsenic contamination in the Kerman Cenozoic Magmatic Arc, Kerman, Iran: Implications for the source identification and regional analysis. Applied Geochemistry, 63, 610-622. https://doi.org/10.1016/j.apgeochem.2015.08. 004

Kikawada, Y., Kawai, S., Shimada, K., \& Oi, T. (2008). Arsenic originating in Kusatsu hot springs, Gunma, Japan. Journal of Disaster Research, 3, 261-269.

Kim, S., Kim, H. B., Kwon, E. E., \& Baek, K. (2021). Mitigating translocation of arsenic from rice field to soil pore solution by manipulating the redox conditions. Science of the Total Environment, 762,. https://doi.org/10.1016/j.scitotenv. 2020.143124

Kim, E. J., Yoo, J. C., \& Baek, K. (2014). Arsenic speciation and bioaccessibility in arsenic-contaminated soils: Sequential extraction and mineralogical investigation. Environmental Pollution, 186, 29-35. https://doi.org/10.1016/j.envpol. 2013.11.032

Le Guern, C., Baranger, P., Crouzet, C., Bodenan, F., \& Conil, P. (2003). Arsenic trapping by iron oxyhydroxides and carbonates at hydrothermal spring outlets. Applied Geochemistry, 18, 1313-1323. https://doi.org/10.1016/S08832927(03)00053-2
Li, S. W., Li, J., Li, H. B., Naidu, R., \& Ma, L. Q. (2015). Arsenic bioaccessibility in contaminated soils: Coupling in vitro assays with sequential and HNO3 extraction. Journal of Hazardous Materials, 295, 145-152. https://doi. org/10.1016/j.jhazmat.2015.04.011

Ljung, K., Oomen, A., Duits, M., Selinus, O., \& Berglund, M. (2007). Bioaccessibility of metals in urban playground soils. Journal of Environmental Science and Health-Part A Toxic/Hazardous Substances and Environmental Engineering, 42(9), 1241-1250. https://doi.org/10.1080/ 10934520701435684

Manfra, L., Masi, U., \& Turi, B. (1976). La composizione isotopica dei travertini del Lazio. Geologia Romana, 15, 127-174. (In Italian).

Martínez-Sánchez, M. J., Martínez-López, S., Martínez-Martínez, L. B., \& Pérez-Sirvent, C. (2013). Importance of the oral arsenic bioaccessibility factor for characterising the risk associated with soil ingestion in a mining-influenced zone. Journal of Environmental Management, 116, 10-17. https://doi.org/10.1016/j.jenvman.2012.11.009

Mikutta, C., Mandaliev, P. N., Mahler, N., Kotsev, T., \& Kretzschmar, R. (2014). Bioaccessibility of arsenic in miningimpacted circumneutral river floodplain soils. Environmental Science and Technology, 48(22), 13468-13477. https://doi.org/10.1021/es502635t

Mingot, J., De Miguel, E., \& Chacón, E. (2011). Assessment of oral bioaccessibility of arsenic in playground soil in Madrid (Spain): A three-method comparison and implications for risk assessment. Chemosphere, 84(10), 1386-1391. https://doi.org/10.1016/j.chemosphere.2011. 05.001

Minissale, A., Kerrick, D. M., Magro, G., Murrell, M. T., Paladini, M., Rihs, S., et al. (2002). Geochemistry of quaternary travertines in the region north of Rome (Italy): Structural, hydrologic and paleoclimatic implications. Earth and Planetary Science Letters, 203(2), 709-728. https://doi.org/10.1016/S0012-821X(02)00875-0

Morelli, G., Rimondi, V., Benvenuti, M., Medas, D., Costagliola, P., Gasparon, M. (2017). Experimental simulation of arsenic desorption from Quaternary aquifer sediments following sea water intrusion. Applied Geochemistry, 87, 176-187

Nelson, C. M., Li, K., Obenour, D. R., Miller, J., Misenheimer, J. C., Scheckel, K., et al. (2018). Relating soil geochemical properties to arsenic bioaccessibility through hierarchical modeling. Journal of Toxicology and Environmental Health, Part A, 81(6), 160-172. https://doi.org/10.1080/ 15287394.2018.1423798

Oomen, A. G., Hack, A., Minekus, M., Zeijdner, E., Cornelis, C., Schoeters, G., et al. (2002). Comparison of five in vitro digestion models to study the bioaccessibility of soil contaminants. Environmental Science and Technology, 36(15), 3326-3334. https://doi.org/10.1021/es010204v

Palumbo-Roe, B., Wragg, J., \& Cave, M. (2015). Linking selective chemical extraction of iron oxyhydroxides to arsenic bioaccessibility in soil. Environmental Pollution, 207, 256-265. https://doi.org/10.1016/j.envpol.2015.09. 026

Peccerillo, A. (2017). The Roman Province. In Cenozoic volcanism in the Tyrrhenian Sea region (pp. 81-124). Springer. 
Pentecost, A. (1995). Geochemistry of carbon dioxide in six travertine-depositing waters of Italy. Journal of Hydrology, 167(1-4), 263-278. https://doi.org/10.1016/00221694(94)02596-4

Pentecost, A. (2005). Travertine. Springer.

Polya, D. A., \& Lawson, M. (2016). Geogenic and anthropogenic arsenic hazard in groundwaters and soils: Distribution, nature, origin, and human exposure routes. In J. C. States (Ed.), Arsenic: Exposure sources, health risks, and mechanisms of toxicity (pp. 23-60). Wiley.

Quansah, R., Armah, F. A., Essumang, D. K., Luginaah, I., Clarke, E., Marfoh, K., et al. (2015). Association of arsenic with adverse pregnancy outcomes/infant mortality: A systematic review and meta-analysis. Environmental Health Perspectives, 123(5), 412-421.

Ravenscroft, P., Brammer, H., \& Richards, K. (2009). Arsenic pollution: A global synthesis. Wiley.

Reimann, C., Matschullat, J., Birke, M., \& Salminen, R. (2009). Arsenic distribution in the environment: The effects of scale. Applied Geochemistry, 24(7), 1147-1167. https:// doi.org/10.1016/j.apgeochem.2009.03.013

Rodriguez, R. R., Basta, N. T., Casteel, S. W., \& Pace, L. W. (1999). An in vitro gastrointestinal method to estimate bioavailable arsenic in contaminated soils and solid media. Environmental Science and Technology, 33(4), 642-649. https://doi.org/10.1021/es980631h

Ruby, M. V., Schoof, R., Brattin, W., Goldade, M., Post, G., Harnois, M., et al. (1999). Advances in evaluating the oral bioavailability of inorganics in soil for use in human health risk assessment. Environmental Science and Technology, 33(21), 3697-3705. https://doi.org/10.1021/es990479z

Salminen, R., Batista, M.J., Bidovec, M., Demetriades, A., De Vivo, B., De Vos, W., Duris, M., Gilucis, A., Gregorauskiene, V., Halamić, J., \& Heitzmann, P. (2005). Geochemical atlas of Europe. Part 1-background information, methodology and maps. Geological Survey of Finland. Otamedia Oy, Espoo (p. 525).

Scrocca, D., Doglioni, C., \& Innocenti, F. (2003). Constraints for an interpretation of the Italian geodynamics: A review. Memorie Descrittive della Carta Geologica d'Italia, 62, $15-46$.

Smith, E., Naidu, R., Weber, J., \& Juhasz, A. L. (2008). The impact of sequestration on the bioaccessibility of arsenic in long-term contaminated soils. Chemosphere, 71(4), 773-780. https://doi.org/10.1016/j.chemosphere.2007.10. 012

Sø, H. U., Postma, D., Jakobsen, R., \& Larsen, F. (2008). Sorption and desorption of arsenate and arsenite on calcite. Geochimica et Cosmochimica Acta, 72(24), 5871-5884. https://doi.org/10.1016/j.gca.2008.09.023

Strangio, D., \& Teodori, M. (2015). Le Terme di Viterbo: dal termalismo sociale ai progetti di rilancio nel segno del turismo del benessere. Agua y Territorio, 6, 80-96. https:// doi.org/10.17561/at.v0i6.2811

US EPA (1989). Risk assessment guidance for superfund volume I human health evaluation manual (part A). U.S. Environmental Protection Agency EPA/540/1-89/002, Office of Emergency and Remedial Response, Washington, DC.

US EPA (1992). Guidelines for exposure assessment. U.S. Environmental Protection Agency EPA/600/Z-92/001.
Risk Assessment Forum U.S. Environmental Protection Agency, Washington, DC.

US EPA (2001). Risk assessment guidance for superfund: Volume III part a, process for conducting probabilistic risk assessment. US Environmental Protection Agency, Washington, D.C. EPA 540-R-02-002.

US EPA (2004). Risk assessment guidance for superfund volume I: Human health evaluation manual (part e, supplemental guidance for dermal risk assessment). U.S. Environmental Protection Agency, EPA/540/R/99/005 Office of Superfund Remediation and Technology Innovation U.S. Environmental Protection Agency Washington, DC.

US EPA (2007a). Guidance for evaluating the oral bioavailability of metals in soils for use in human health risk assessment. OSWER 9285.7-80. http://www.epa.gov/ superfund/health/contaminants/bioavailability/guidance. htm

US EPA (2007b). Estimation of relative bioavailability of lead in soil and soil-like materials using in vivo and in vitro methods. OSWER 9285.7-77. http://www.epa.gov/ superfund/health/contaminants/bioavailability/guidance. htm

US EPA (2010). Region 9, regional screening levels. http:// www.epa.gov/region9/superfund/prg/index.html

US EPA (2012). Standard operating procedure for an in vitro bioaccessibility assay for lead in soil. EPA 9200.2-86.

Vivona, R., Preziosi, E., Madé, B., \& Giuliano, G. (2007). Occurrence of minor toxic elements in volcanic-sedimentary aquifers: A case study in central Italy. Hydrogeology Journal, 15(6), 1183-1196. https://doi.org/10.1007/ s10040-007-0169-x

Webster, J. G., \& Nordstrom, D. K. (2003). Geothermal arsenic. In A. H. Welch \& K. G. Stollenwerk (Eds.), Arsenic in groundwater: Geochemistry and occurrence (pp. 101-126). Springer.

Wedepohl, K. H. (1995). The composition of the continental crust. Geochimica et Cosmochimica Acta, 59(7), 1217-1232. https://doi.org/10.1016/0016-7037(95)000382

Wenzel, W. W., Kirchbaumer, N., Prohaska, T., Stingeder, G., Lombi, E., \& Adriano, D. C. (2001). Arsenic fractionation in soils using an improved sequential extraction procedure. Analytica Chimica Acta, 436(2), 309-323. https://doi.org/ 10.1016/S0003-2670(01)00924-2

Whitacre, S. D., Basta, N. T., \& Dayton, E. A. (2013). Bioaccessible and non-bioaccessible fractions of soil arsenic. Journal of Environmental Science and Health-Part A Toxic/Hazardous Substances and Environmental Engineering, 48(6), 620-628. https://doi.org/10.1080/ 10934529.2013.731804

Winkel, L. H. E., Casentini, B., Bardelli, F., Voegelin, A., Nikolaidis, N. P., \& Charlet, L. (2013). Speciation of arsenic in Greek travertines: Co-precipitation of arsenate with calcite. Geochimica et Cosmochimica Acta, 106, 99-110. https://doi.org/10.1016/j.gca.2012.11.049

Yokoyama, Y., Mitsunobu, S., Tanaka, K., Itai, T., \& Takahashi, Y. (2009). A study on the coprecipitation of arsenite and arsenate into calcite coupled with the determination of oxidation states of arsenic both in calcite and water. 
Chemistry Letters, 38(9), 910-911. https://doi.org/10. 1246/cl.2009.910

Yokoyama, Y., Tanaka, K., \& Takahashi, Y. (2012). Differences in the immobilization of arsenite and arsenate by calcite. Geochimica et Cosmochimica Acta, 91, 202-219. https://doi.org/10.1016/j.gca.2012.05.022

Zeng, H., Fisher, B., \& Giammar, D. E. (2008). Individual and competitive adsorption of arsenate and phosphate to a highsurface-area iron oxide-based sorbent. Environmental Science and Technology, 42(1), 147-152.
Zuzolo, D., Cicchella, D., Demetriades, A., Birke, M., Albanese, S., Dinelli, E., et al. (2020). Arsenic: Geochemical distribution and age-related health risk in Italy. Environmental Research, 182,. https://doi.org/10.1016/j.envres.2019. 109076

Publisher's Note Springer Nature remains neutral with regard to jurisdictional claims in published maps and institutional affiliations. 